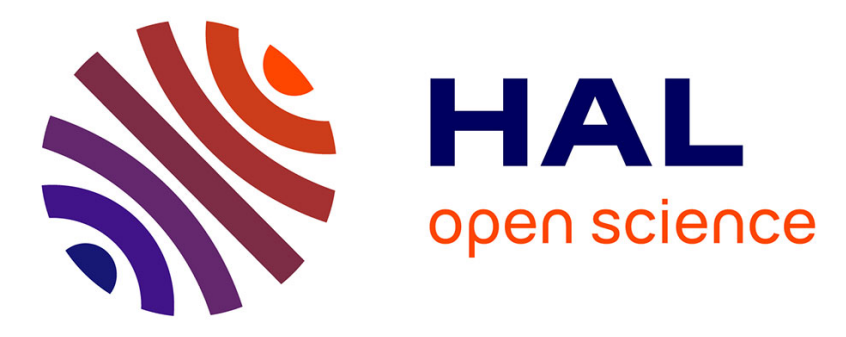

\title{
Ocean acidification causes variable trait-shifts in a coral species
}

\author{
Núria Teixidó, Erik Caroselli, Samir Alliouane, Chiara Ceccarelli, Steeve \\ Comeau, Jean-Pierre Gattuso, Pietro Fici, Fiorenza Micheli, Alice Mirasole, \\ Stephen Monismith, et al.
}

\section{To cite this version:}

Núria Teixidó, Erik Caroselli, Samir Alliouane, Chiara Ceccarelli, Steeve Comeau, et al.. Ocean acidification causes variable trait-shifts in a coral species. Global Change Biology, 2020, 26 (12), pp.6813-6830. 10.1111/gcb.15372 . hal-03374987

\section{HAL Id: hal-03374987 \\ https://hal.science/hal-03374987}

Submitted on 12 Oct 2021

HAL is a multi-disciplinary open access archive for the deposit and dissemination of scientific research documents, whether they are published or not. The documents may come from teaching and research institutions in France or abroad, or from public or private research centers.
L'archive ouverte pluridisciplinaire HAL, est destinée au dépôt et à la diffusion de documents scientifiques de niveau recherche, publiés ou non, émanant des établissements d'enseignement et de recherche français ou étrangers, des laboratoires publics ou privés. 


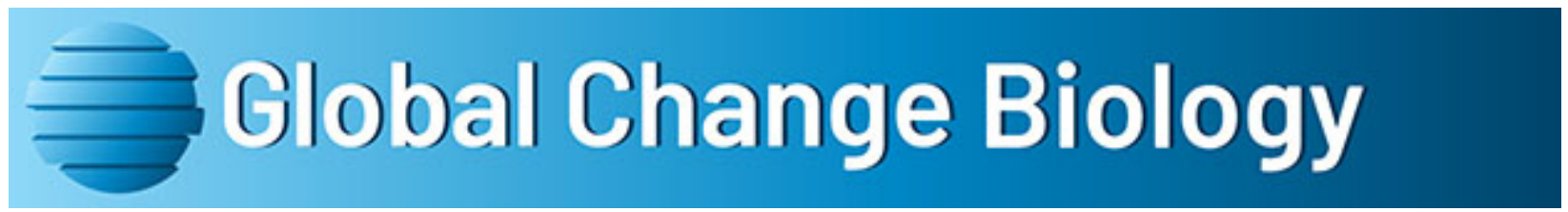

\section{Ocean acidification causes variable trait shifts in a coral species}

\begin{tabular}{|c|c|}
\hline Journal: & Global Change Biology \\
\hline Manuscript ID & GCB-20-1585 \\
\hline Wiley - Manuscript type: & Primary Research Articles \\
\hline $\begin{array}{r}\text { Date Submitted by the } \\
\text { Author: }\end{array}$ & 24-Jul-2020 \\
\hline Complete List of Authors: & $\begin{array}{l}\text { Teixido, Nuria; Stazione Zoologica Anton Dohrn, Villa Dohrn-Benthic } \\
\text { Ecology Center; CNRS-UPMC, Laboratoire d'Océanographie de } \\
\text { Villefranche } \\
\text { Caroselli, Erik; Alma Mater Studiorum - University of Bologna, } \\
\text { Department of Biological, Geological, and Environmental Sciences, } \\
\text { University of Bologna } \\
\text { Alliouane, Samir; CNRS-UPMC, Laboratoire d'Océanographie de } \\
\text { Villefranche } \\
\text { Ceccarelli, Chiara; Alma Mater Studiorum - University of Bologna, } \\
\text { Department of Biological, Geological, and Environmental Sciences } \\
\text { Comeau, Steeve; CNRS-UPMC, Laboratoire d'Océanographie de } \\
\text { Villefranche } \\
\text { Gattuso, Jean-Pierre; CNRS-UPMC, Laboratoire d'Océanographie de } \\
\text { Villefranche } \\
\text { Fici, Pietro; Alma Mater Studiorum - University of Bologna, Department } \\
\text { of Biological, Geological, and Environmental Sciences } \\
\text { Micheli, Fiorenza; Stanford University, Hopkins Marine Station } \\
\text { Mirasole, Alice; Stazione Zoologica Anton Dohrn } \\
\text { Monismith, Stephen; Stanford University, Department of Civil and } \\
\text { Environmental Engineering } \\
\text { Munari, Marco; Stazione Zoologica Anton Dohrn, Villa Dohrn-Benthic } \\
\text { Ecology Center } \\
\text { Palumbi, Stephen; Stanford University, Hopkins Marine Station } \\
\text { Sheets, Elisabeth; Stanford University, Hopkins Marine Station } \\
\text { Urbini, Lidia; Istituto Nazionale di Oceanografia e Geofisica Sperimentale } \\
\text { De Vittor, Cinzia; Istituto Nazionale di Oceanografia e Geofisica } \\
\text { Sperimentale } \\
\text { Goffredo, Stefano; Alma Mater Studiorum - University of Bologna, } \\
\text { Department of Biological, Geological and Environmental Sciences } \\
\text { Gambi, Maria Cristina; Stazione Zoologica Anton Dohrn, Villa Dohrn- } \\
\text { Benthic Ecology Center }\end{array}$ \\
\hline Keywords: & $\begin{array}{l}\text { corals, calcification, ocean acidification, variable environments, natural } \\
\mathrm{CO}<\text { sub }>2</ \text { sub }>\text { vents, acclimatization/adaptation }\end{array}$ \\
\hline Abstract: & $\begin{array}{l}\text { High } p \mathrm{CO}_{2} \text { habitats and their populations provide an unparalleled } \\
\text { opportunity to assess how species may survive under future ocean } \\
\text { acidification conditions, and help to reveal the traits that confer } \\
\text { tolerance. Here we utilize a unique } \mathrm{CO}_{2} \text { vent system to study the effects }\end{array}$ \\
\hline
\end{tabular}


of exposure to elevated $p \mathrm{CO}_{2}$ on trait-shifts observed throughout natural populations of Astroides calycularis, an azooxanthellate scleractinian coral endemic to the Mediterranean. Unexpected shifts in skeletal and growth patterns were found. Colonies shifted to a skeletal phenotype characterized by encrusting morphology, smaller size, reduced coenosarc tissue, fewer polyps, and less porous and denser skeletons at low $\mathrm{pH}$. Interestingly, while individual polyps calcified more and extended faster at low $\mathrm{pH}$, whole colonies found at low $\mathrm{pH}$ site calcified and extended their skeleton at the same rate as did those at ambient $\mathrm{pH}$ sites. Transcriptomic data revealed strong genetic differentiation among local populations of this warm water species whose distribution range is currently expanding northward. We found excess differentiation in the $\mathrm{CO}_{2}$ vent population for genes central to calcification, including genes for calcium management (calmodulin, calcium-binding proteins), $\mathrm{pH}$ regulation ( $\mathrm{V}$-type proton ATPase), and inorganic carbon regulation (carbonic anhydrase). Combined, our results demonstrate how coral populations can persist in high $p \mathrm{CO}_{2}$ environments, making this system a powerful candidate for investigating acclimatization and local adaptation of organisms to global environmental change.

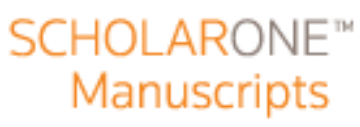


2

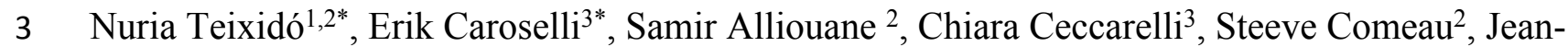

4 Pierre Gattuso $^{2,4}$, Pietro Fici ${ }^{3}$, Fiorenza Micheli ${ }^{5,6}$, Alice Mirasole ${ }^{1}$, Stephen G. Monismith ${ }^{7}$,

5 Marco Munari ${ }^{1}$, Stephen R. Palumbi ${ }^{5}$, Elizabeth Sheets ${ }^{5}$, Lidia Urbini ${ }^{8}$, Cinzia De Vittor ${ }^{8}$,

6 Stefano Goffredo ${ }^{3,9^{*}}$, Maria Cristina Gambi ${ }^{1}$

7

$8{ }^{1}$ Stazione Zoologica Anton Dohrn, Ischia Marine Centre, Punta San Pietro 80077, Ischia, Naples,

$9 \quad$ Italy.

10 2Sorbonne Université, CNRS, Laboratoire d'Océanographie de Villefranche, 181 chemin du

11 Lazaret, 06230 Villefranche-sur-mer, France.

$12{ }^{3}$ Marine Science Group, Department of Biological, Geological, and Environmental Sciences,

13 University of Bologna, Via Selmi 3, 40126 Bologna, Italy.

$14{ }^{4}$ Institute for Sustainable Development and International Relations, Sciences Po, 27 rue Saint

15 Guillaume, F-75007 Paris, France

$16{ }^{5}$ Department of Biology, Hopkins Marine Station, Stanford University, Pacific Grove, CA, 1793950 , USA.

$18{ }^{6}$ Stanford Center for Ocean Solutions, Pacific Grove, CA, 93950, USA.

$19{ }^{7}$ Department of Civil and Environmental Engineering, Stanford University, Stanford, CA, 94305, 20 USA.

$21{ }^{8}$ Istituto Nazionale di Oceanografia e di Geofisica Sperimentale (OGS), Via A. Piccard 54, 2234151 , Trieste, Italy.

$23{ }^{9}$ Fano Marine Center, Department of Biological, Geological and Environmental Sciences, 
24 University of Bologna, viale Adriatico 1/N, 61032 Fano, Italy

25 *corresponding author. Email: nuria.teixido@obs-vlfr.fr ; erik.caroselli@unibo.it ;

26 s.goffredo@unibo.it

27 


\section{Abstract}

29 High $p \mathrm{CO}_{2}$ habitats and their populations provide an unparalleled opportunity to assess how species may survive under future ocean acidification conditions, and help to reveal the traits that

31 confer tolerance. Here we utilize a unique $\mathrm{CO}_{2}$ vent system to study the effects of exposure to

32 elevated $p \mathrm{CO} 2$ on trait-shifts observed throughout natural populations of Astroides calycularis, an

33 azooxanthellate scleractinian coral endemic to the Mediterranean. Unexpected shifts in skeletal

34 and growth patterns were found. Colonies shifted to a skeletal phenotype characterized by 35 encrusting morphology, smaller size, reduced coenosarc tissue, fewer polyps, and less porous and 36 denser skeletons at low pH. Interestingly, while individual polyps calcified more and extended

37 faster at low $\mathrm{pH}$, whole colonies found at low $\mathrm{pH}$ site calcified and extended their skeleton at the 38 same rate as did those at ambient $\mathrm{pH}$ sites. Transcriptomic data revealed strong genetic 39 differentiation among local populations of this warm water species whose distribution range is 40 currently expanding northward. We found excess differentiation in the $\mathrm{CO}_{2}$ vent population for 41 genes central to calcification, including genes for calcium management (calmodulin, calcium42 binding proteins), $\mathrm{pH}$ regulation (V-type proton ATPase), and inorganic carbon regulation 43 (carbonic anhydrase). Combined, our results demonstrate how coral populations can persist in high $44 \quad p \mathrm{CO}_{2}$ environments, making this system a powerful candidate for investigating acclimatization and 45 local adaptation of organisms to global environmental change. 


\section{INTRODUCTION}

49 Understanding the effects of environmental variability and extremes on natural populations and ecosystems is a key priority as global environmental change intensifies (Bennett, Duarte, Marba,

51 \& Wernberg, 2019; Bozinovic, Calosi, \& Spicer, 2011). High local variability in physical and

52 chemical ocean properties can create extreme climatic environments, where marine species persist

53 under suboptimal environmental conditions such as highly variable temperatures, marginal

54 habitats at latitudinal extremes, and acidification at $\mathrm{CO}_{2}$ vent sites (Camp et al., 2018; Kapsenberg

55 \& Cyronak, 2019; Kroeker et al., 2019). Populations living in these unique settings experience

56 high environmental variability and can have broad physiological tolerance to environmental

57 stressors that would prevent survival of conspecifics living in less variable micro-environments

58 (Bozinovic et al., 2011; Thomas et al., 2018). Two important mechanisms for intraspecific

59 variation in tolerance to environmental variability and extremes are adjusting life traits through

60 phenotypic plasticity and local adaptation, and these processes may interact synergistically

61 (Hoffmann \& Sgro, 2011; Savolainen, Lascoux, \& Merilä, 2013). Phenotypic plasticity (also

62 referred to as acclimatization) is the ability of a genotype to produce different morphological and

63 physiological responses when exposed to different environmental conditions within an organism's

64 lifespan, resulting in a phenotypic shift that is plastic and often reversible (Savolainen et al., 2013;

65 Thomas et al., 2018). Adaptation is the result of natural selection on beneficial genotypes in a 66 population where these changes are heritable and passed on to the next generation (Hoffmann \&

67 Sgro, 2011; Savolainen et al., 2013). Natural extreme environments are potential locations for climate-adapted populations where, for example, microhabitats experiencing periodic temperature extremes have shown to generate high-tolerance in some reef-building corals (Palumbi, Barshis,

70 Traylor-Knowles, \& Bay, 2014; Thomas et al., 2018). However, there is still much to learn about 
71 the underlying mechanisms of acclimatization and adaptation to climate variability and extremes

72 by studying populations in naturally variable environments. Such studies are critical for predicting

73 future biological responses to rapid global environmental change.

74 Insights into species' tolerance to environmental change may be gained by analyzing traits that 75 directly influence an organism's performance (Mouillot, Graham, Villéger, Mason, \& Bellwood, 76 2013). Shifts in the occurrence of these traits under variable environmental conditions can reflect 77 patterns of differential survival and growth strategies; for example, different morphological forms 78 (e.g. massive or encrusting), longevity, size, growth rates, physical defenses and dispersal ability 79 (Darling, Alvarez-Filip, Oliver, Mcclanahan, \& Côté, 2012; Teixidó et al., 2018). These traits 80 provide relevant information about life strategies that are the result of different evolutionary and 81 ecological processes and influence, both the fitness of individuals and the viability of natural 82 populations (Darling et al., 2012; Mouillot et al., 2013; Teixidó et al., 2018). However, we still 83 know comparatively little about trait-shifts within natural populations and the capacity to adapt to 84 long-term novel environmental conditions.

85 Natural volcanic $\mathrm{CO}_{2}$ vents cause local acidification of seawater and are used as a proxy to study 86 future ocean acidification (Enochs et al., 2015; Fabricius et al., 2011; Hall-Spencer et al., 2008).

87 Ocean acidification reflects a suite of changes in seawater carbonate chemistry due to the uptake 88 of excess anthropogenic $\mathrm{CO}_{2}$ by the ocean, resulting in a decline in the surface ocean $\mathrm{pH}$, carbonate 89 ion concentration, and saturation state of calcium carbonate minerals (e.g. aragonite), while 90 increasing the partial pressure of carbon dioxide $\left(p \mathrm{CO}_{2}\right)$ and bicarbonate ion concentrations 91 (Doney, Fabry, Feely, \& Kleypas, 2009). Low pH levels in natural $\mathrm{CO}_{2}$ vents represent future 92 climatic conditions where, relative to 1870 , surface $\mathrm{pH}$ is projected to decline by -0.14 to $-0.4 \mathrm{pH}$ 93 units by 2100, under IPCC Representative Concentration Pathways (RCP) RCP 2.6 (low $\mathrm{CO}_{2}$ 
emissions) and RCP 8.5 (high $\mathrm{CO}_{2}$ emissions) (Fabricius et al., 2011; Gattuso et al., 2015; Goffredo et al., 2014; Teixidó et al., 2018). Although these $\mathrm{pH}$ conditions can provide some insight into future acidification scenarios, they are not perfect proxies. One important assumption to consider is that variability of seawater $\mathrm{pH}$ increases with decreasing means at $\mathrm{CO}_{2}$ vent systems. Although variability in $\mathrm{pH} / p \mathrm{CO}_{2}$ will increase with dissolved inorganic carbon due to the thermodynamics of the carbonate system in the future ocean (Takeshita et al., 2015), it is not possible to disentangle the effects of changes in the mean versus variability in this system. Thus, the conditions in the $\mathrm{pH}$ zones should be considered as $\mathrm{pH}$ regimes, with decreases in mean $\mathrm{pH}$ coinciding with increases in variability. Nevertheless, these high $p \mathrm{CO}_{2}$ environments and their populations provide an unparalleled opportunity to assess how species may survive into future $\mathrm{pH}$ conditions and to reveal if general traits that confer tolerance can be identified.

Corals are key marine organisms that are particularly vulnerable to the impacts of climate change and ocean acidification (Brandl et al., 2019; Gattuso et al., 2015). They create habitats for many species, enhancing biodiversity, playing fundamental ecological roles and sustaining ecosystem processes and services such as fisheries, coastal protection and tourism (Brandl et al., 2019; Gattuso et al., 2015). Ocean acidification may pose a major threat to corals because their growth relies on the precipitation of calcium carbonate (calcification), a process that is expected to decrease as seawater acidity increases (Chan \& Connolly, 2013). Studies conducted at $\mathrm{CO}_{2}$ vent ecosystems on native corals have reported an overall decline in species abundances, decreases in calcification and skeletal density with increasing acidification (Fabricius et al., 2011; Fantazzini et al., 2015; Goffredo et al., 2014).

Here we utilize a unique $\mathrm{CO} 2$ vent system to investigate the effects of exposure to elevate $p \mathrm{CO}_{2}$ on trait-shifts on Astroides calycularis, an azooxanthellate scleractinian coral endemic to the 
117 Mediterranean, that naturally occurs in the acidified environment of a newly discovered $\mathrm{CO}_{2}$ vent 118 system in Ischia, Italy. This $\mathrm{CO}_{2}$ vent system locally acidifies the seawater with gas comprising 92-95\% $\mathrm{CO}_{2}$ (no sulphur, and no temperature anomaly). A. calycularis is a long-lived coral (large colonies may have a life span of several decades), considered a warm-water species with a narrow temperature tolerance confined to $14^{\circ} \mathrm{C}$ during winter (Bianchi, 2007; Zibrowius, 1995). A. 122 calycularis has low dispersal capacities, and therefore restricted gene flow (Casado-Amezúa, 123 Goffredo, Templado, \& Machordom, 2012). Because A. calycularis is a calcifying and long-lived 124 species with low dispersal capacity, and found throughout the $\mathrm{CO}_{2}$ vents, it is a great model system 125 for investigating variation in local climate phenotypic plasticity and adaptation. Previous research 126 on the effects of ocean acidification on A. calycularis has shown contrasting results: a reduction 127 of net calcification rates was found when colonies growing in ambient $\mathrm{pH}$ conditions were 128 transplanted to a vent system with $\mathrm{pH}$ below 7.7 (Prada et al., 2017), while no change in calcification under acidification was observed in controlled laboratory conditions (Movilla et al., 2016). We compare populations living near the vent to two reference areas outside the influence of $\mathrm{CO}_{2}$ venting to examine the effects of low $\mathrm{pH}$ conditions on A. calycularis traits, to characterize the genetic population structure, and to identify differentiation in genes that are central to calcification. Specifically, we addressed the following questions: i) do populations at the $\mathrm{CO}_{2}$ vent

134 and reference sites exhibit significant trait variation?, ii) do these nearby populations display 135 genetic differentiation?, and iii) does the $\mathrm{CO}_{2}$ vent population have highly divergent SNP 136 genotypes from calcium- related loci? To answer these questions, we characterized the physical 137 and chemical parameters of the study sites and combined in situ population demographics, skeletal 138 characteristics, computed tomography and transcriptomic approaches to assess changes in 139 population abundance, skeletal properties, age, and genomics of differentiation of $A$. calycularis. 
140

141

142

143

144

145

146

147

148

149

150

151

152

153

154

155

156

157

158

159

160

161

162

\section{MATERIAL AND METHODS}

\subsection{Experimental design and study sites}

Here we compare natural populations of the scleractinian coral A. calycularis at a volcanic $\mathrm{CO}_{2}$ vent and two nearby reference sites with ambient $\mathrm{pH}$ and no vent activity along the coast of Ischia, Italy (Figure 1). The $\mathrm{CO}_{2}$ vent system is located at a $5 \mathrm{~m}$ depth inside a semi-submerged cave of volcanic origin named Grotta del Mago (Magician's Cave, 4042'41.87"N, 1357'51.06"E, hereafter Vent system) (Figure 1). The cave (total length of $110 \mathrm{~m}$ ) consists of a main outer chamber (10 m wide x $30 \mathrm{~m}$ long), connected to an inner chamber by a long narrow passage (Cinelli et al., 1977). Published studies and personal observations indicated an increase in the $\mathrm{CO}_{2}$ vent activity over the last 50 years in the main chamber, with limited vent activity in the 70 's (Cinelli et al., 1977) and 2000's (Dappiano \& Gambi, 2004) developing into intense activity from 2014 onwards. The abundance of $A$. calycularis in the cave has increased over time, with a low and patchy distribution between 1-2 m depth in the main chamber in the 1970's (Cinelli et al., 1977) to a high and continuous distribution in the 2000's (Dappiano \& Gambi, 2004). The present study was performed in the main chamber of the cave. The reference sites with ambient $\mathrm{pH}$ were chosen following the criteria: i) A. calycularis naturally occurred there, ii) they hosted similar habitats and depths as the $\mathrm{CO}_{2}$ vent site, and iii) and no venting activity was evident. Two reference sites were selected: Punta Vico $\left(40^{\circ} 45^{\prime} 32.28^{\prime \prime} \mathrm{N}, 13^{\circ} 52^{\prime} 55.38^{\prime \prime} \mathrm{E}\right.$, another semi-submerged cave, with a main chamber $10 \mathrm{~m}$ wide x $30 \mathrm{~m}$ long, $5 \mathrm{~m}$ maximum depth, hereafter Ambient 1); and Sant'Angelo (4041'33.78"N, 13 ${ }^{\circ} 53^{\prime} 38.88^{\prime \prime}$, an overhang, also a natural habitat of $A$. calycularis, located on a natural arch, with an opening of $10 \mathrm{~m}$ wide $\mathrm{x} 10 \mathrm{~m}$ height, $10 \mathrm{~m}$ maximum depth, hereafter Ambient 2). Initial investigations of the natural systems and environmental parameters started in June, 2016. These preliminary environmental data were used to plan subsequent field 
163 samplings of the carbonate chemistry associated with the $\mathrm{CO}_{2}$ vent system and reference sites in

164 September, 2018 and June, 2019.

$165 \quad 2.2$ The coral

166 A. calycularis (Pallas, 1766) is an azooxanthellate scleractinian colonial coral endemic to the

167 Mediterranean, characterized by the bright orange color of its coenosarc and polyps (Zibrowius,

168 1995). It is considered a long-lived species (e.g large colonies may have a life span of several 169 decades) and commonly found in dimly lit, shallow rocky habitats (vertical walls, cave entrances, 170 overhangs, from the intertidal fringe to $50 \mathrm{~m}$ depths) (Zibrowius, 1995). It can be highly abundant 171 covering more than $90 \%$ of local reefs. It has a limited geographic distribution, with a southwestern 172 distribution in the Mediterranean Sea (Zibrowius, 1995). This coral is considered a warm-water 173 species with a narrow temperature tolerance confined to $14^{\circ} \mathrm{C}$ during the winter (Bianchi, 2007).

174 Fossil records reveal this species lived in the northwestern Mediterranean during part of the 175 Pleistocene, where climatic fluctuations occurred leading to a reduction of the species (Zibrowius, 176 1995). Interestingly, observed records north of its known distribution range in Italy and Croatia 177 suggest that it is currently expanding northward (Bianchi, 2007). Currently, A. calycularis is 178 assessed as vulnerable on the IUCN Red List due to its limited geographic distribution and the 179 historical and current regression caused by human activities in the littoral zone. A. calycularis 180 broods its larvae and has relatively low dispersal capacity (Casado-Amezúa et al., 2012).

\subsection{Gas and temperature}

182 Gas samples were collected in $200 \mathrm{ml}$ glass bottles and analyzed using gas chromatography 183 (Agilent 7890B combined with a Micro GC analyzer-INFICON, held at a constant temperature of $\left.18480{ }^{\circ} \mathrm{C}\right)$. The mean composition of the bubbling gas was predominantly $\mathrm{CO}_{2}(92-95 \%$, with 185 undetectable levels of sulfur gas $<0.0002 \%$ ) and did not elevate the temperature (see Supporting 
Note 1, Figure S1), subsequently resulting in water acidification. Vent activity was sampled by counting the number of vents in randomly placed $1 \mathrm{~m}^{2}$ quadrats $(\mathrm{n}=11)$ in the main chamber, with approximately 5 vents $\mathrm{m}^{-2}$ (mean $\pm \mathrm{SE}=4.9 \pm 2.7$ vents $\mathrm{m}^{-2}$, $\min =2$ vents $\mathrm{m}^{-2}$; maximum $=11$ vents $\mathrm{m}^{-2}$ ). Temperature was registered every hour by in situ temperature data loggers (Hobo TidbiT v2, Onset) in the cave and the reference areas and followed ambient seasonal fluctuations, from 14.7 to $15.2^{\circ} \mathrm{C}$ in winter ( $\left.\mathrm{n}=16,754\right)$, and from 25.5 to $26.5^{\circ} \mathrm{C}$ in summer $(\mathrm{n}=19,011)$ over a 3-year period from 2016 to 2019 at $2 \mathrm{~m}$ depth (Figure S1, Table S1).

\section{$2.4 \mathrm{pH}_{\mathrm{T}}$ time series, $\mathrm{pH}_{\mathrm{T}}$ variability and $\mathrm{pH}$ sensor calibration}

SeaFET ${ }^{\mathrm{TM}}$ Ocean $\mathrm{pH}$ sensors (Satlantic) were deployed to quantify variation in $\mathrm{pH}$ inside the cave at 2, 3 and $4 \mathrm{~m}$ depth. They were deployed in May-June (before summer) and in September (after summer) to assess whether differences in water temperature stratification could influence $\mathrm{pH}$ across depths. Dates of deployment were from September 8 to September 24, 2018 and from May 30 to June 18,2019 . Two sensors were deployed in the reference areas during the same period (Ambient 1 in September, 2018 and Ambient 2 in June, 2019). Before deployment, the SeaFETs were calibrated with ambient $\mathrm{pH}$ water in the aquarium facilities at the Center Villa Dohrn (Ischia, Italy) (for full details of $\mathrm{pH}$ sensor calibration, see Supporting Methods). The mean offset between calibration samples and calibrated SeaFET $\mathrm{pH}$ was \pm 0.002 units, indicating high quality $\mathrm{pH}$ dataset (Figure S2).

\subsection{Carbonate Chemistry and Nutrients}

Discrete water samples were collected using Niskin bottles at the vent and reference areas with ambient $\mathrm{pH}$ to measure: i) the carbonate system parameters during the $\mathrm{pH}$ sensor deployment, and ii) dissolved inorganic nutrients. Salinity was measured using a CTD (CTD Sea Bird Electronics SBE 19 Plus Seacat). Samples for total alkalinity $\left(\mathrm{A}_{\mathrm{T}}\right)$ were collected using standard operating 
209 protocols (for full details, see Supporting Methods). The $\mathrm{HCl}(0.1 \mathrm{M})$ titrant solution was

210 calibrated against certified reference materials distributed by A.G. Dickson (CRM, Batches \#153,

$211 \# 171$, and \#177). Precision of the $A_{T}$ measurements of CRMs was $<2.0 \mu \mathrm{mol} \mathrm{kg}^{-1}$ from nominal

212 values. Means were reported as (mean $\pm \mathrm{SD}$ ): $\mathrm{A}_{\mathrm{T}}=2562.41 \pm 7.8 \mu \mathrm{mol} \mathrm{kg}^{-1}, \mathrm{n}=27$ in September

2132018 ; and $\mathrm{A}_{\mathrm{T}}=2543.57 \pm 21.78 \mu \mathrm{mol} \mathrm{kg}-1, \mathrm{n}=21$ in June 2019. $\mathrm{A}_{\mathrm{T}}$ and $\mathrm{pH}_{\mathrm{T}}$ were used to determine

214 the remaining carbonate system parameters at in situ temperature and depth of each sampling

215 period in the R package seacarb v3.2.12 (for constant details, see Supporting Methods). Dissolved

216 inorganic nutrients (nitrite $\mathrm{NO}_{2}$, nitrate $\mathrm{NO}_{3}$, ammonium $\mathrm{NH}^{+}$, phosphate $\mathrm{PO}_{4}$ and silicate

$\left.217 \mathrm{Si}(\mathrm{OH})_{4}\right)$ were determined using a colorimetric method (Supporting Methods) (Table S2).

218

2.6 Coral field surveys: cover, population structure and morphology

219 The $A$. calycularis cover was quantified using 24 photoquadrats $(25 \times 25 \mathrm{~cm})$ positioned along six

220 transects at four depths: 1, 2, 3, and $4 \mathrm{~m}$ in the three study sites (Vent, A1, A2). Percentage cover

221 was analyzed with ImageJ image software (National Institutes of Health,

222 https://imagej.net/ImageJ). Size frequency-distribution was calculated at 1 and $3 \mathrm{~m}$ depths by

223 counting the number of polyps of each colony and each colony was then pooled into one of five

224 size classes (I: 1-5 polyps: II: 6-10 polyps; III: 11-15 polyps; IV: 16-20 polyps; V: > 20 polyps).

225 These size classes were selected to span the range of colony sizes encountered in the field. We

226 also assessed necrosis as the percentage of the colony exhibiting dead tissue or denuded skeleton,

227 from white-grey to unpigmented or denuded skeleton. Finally, visual assessments were used to

228 classify the colonies into two morphological categories: encrusting (flat growth form) and massive

229 (extensive vertical and lateral growth). Encrusting colonies extended laterally over the surrounding

230 substrate, whereas massive presented a greater vertical accretion which resulted in semi-spherical 
231 shapes. This categorical criterion allowed us to obtain two simple morphological variables to 232 capture biologically relevant axes of variation.

\subsection{Sample collection for presence of coenosarc, skeletal characteristics and growth}

234 Sixty-six colonies of $A$. calycularis were sampled haphazardly for coenosarc, biometric, growth, 235 and skeletal parameters. Thirty-four colonies were collected at the vent site: 16 colonies were obtained from the vicinity of the $\mathrm{CO}_{2}$ vents at $3 \mathrm{~m}$ depth (vent system deep, $\mathrm{Vd}$ ) and 18 colonies at $1-2 \mathrm{~m}$ depth (vent system shallow, Vs). Thirty-two colonies were collected from areas with ambient pH conditions: 17 colonies in Punta Vico, Ambient 1, 1-2 m depth; and 15 colonies in Sant'Angelo, Ambient 2, 1 -2 m depth. The 66 colonies were photographed and the percentage of coenosarc (i.e., the living tissue connecting the polyps) was determined. The $\%$ of coenosarc was determined from the edges of the polyp tissue. The \% of coenosarc was classified into ten classes at every $10 \%$ interval, from $100 \%$ to $0 \%$. Loss of coenosarc in A. calycularis may occur mainly by two mechanisms: 1) loss of tissue due to necrosis (when colony exhibits dead tissue, from white-grey to unpigmented or denuded skeleton), or 2) the coenosarc is already absent due to 245 physiological and morphological characteristic of the colonies.

\subsubsection{Biometric parameters}

247 Coral skeletons were rinsed in a solution of $10 \%$ commercial chlorine bleach for 3-4 days to 248 dissolve polyp tissue, then they were dried at room temperature for 3 days. Colony was defined as 249 the whole calcareous skeleton, which included the polyps (corallites) and the coenosteum. The 250 following parameters were measured: colony length $\left(\mathrm{L}_{\mathrm{c}}\right.$, major axis of the colony) and colony 251 width ( $\mathrm{W}_{\mathrm{c}}$, minor axis of the colony); number of polyps in each colony $\left(\mathrm{NP}_{\mathrm{c}}\right)$, corallite length $\left(\mathrm{L}_{\mathrm{p}}\right.$, 252 maximum axis of the oral disc) and corallite width $\left(\mathrm{W}_{\mathrm{p}}\right.$, minimum axis of the oral disc) (for full 253 details, see Supporting Methods, Figures S3-S4, and Tables S3-S4). 


\subsubsection{Growth and age estimations}

255 The age of each corallite skeleton was determined by counting the growth bands of 49-70 randomly 256 selected corallites per site, by means of computerized tomography (CT). Growth bands are

257 distinguished by a high-density band in winter and a low-density band in summer in temperate 258 corals (see Supporting Methods). The age of all collected corallites was estimated using the von 259 Bertalanffy's length-age growth function derived from the CT growth bands analysis. Coral 260 growth is described by three parameters: linear extension rate (linear growth), net calcification rate 261 (net mass deposited) and bulk skeletal density (mass per volume unit) (Goffredo et al., 2009). The measurement of all three components is fundamental when assessing the effect of the environment on coral growth, since none of the three parameters is a perfect predictor for the other two and

264 each species can respond differently to environmental conditions. Then, the following three coral 265 growth parameters were calculated for both polyp and colony levels: 1) linear extension rate; 2) 266 net calcification rate and 3) bulk skeletal density (see below for bulk skeletal density 267 measurements) (for full details, see Supporting Methods).

\subsubsection{Skeletal parameters}

269 Skeletal parameters of colonies were calculated by applying the buoyant weight technique through the density determination kit of the Ohaus Explorer Pro balance $( \pm 0.0001 \mathrm{~g}$; for further details,

271 see Supporting Methods). This method is based on the Archimedes principle applied to a specimen

272 after full saturation with the same fluid in which it was submerged. The measurements required to 273 calculate the skeletal parameters were: density of the fluid medium ( $\rho$ ); dry mass (DW), buoyant 274 weight of the skeleton (BW= weight of the skeleton minus weight of the water displaced by it), 275 SW (saturated weight of the coral = weight of the skeleton plus weight of the water enclosed in 276 its). Measurements were repeated three times to get an average for BW and SW. Based on these 
277 measurements, the following parameters were calculated: $\mathrm{V}_{\text {MATRIX }}$ (matrix volume $=$ volume of

278 the skeleton, excluding the volume of its pores); $\mathrm{V}_{\text {PORES }}$ (pore volume $=$ volume of the pores in the

279 skeleton), $\mathrm{V}_{\text {ТОт }}$ (bulk volume = total volume of the skeleton including its pores). Finally, the

280 skeletal parameters of colonies were calculated: the micro-density (ratio of DW to $\mathrm{V}_{\text {MATRIX); the }}$

281 bulk density (ratio DW to $\mathrm{V}_{\text {TOT }}$ ); and the porosity (ratio $\mathrm{V}_{\text {PORES }}$ to $\mathrm{V}_{\text {TOT }}$ ).

\subsection{Sample collection for genetics and transcriptome assembly}

283 A. calycularis colonies were haphazardly collected between 1- $2 \mathrm{~m}$ depth to compare gene flow 284 among populations at the study sites. Nineteen colonies from the Vent, 14 colonies from Ambient 2851 and 8 colonies from Ambient 2 were sampled for genetic analysis. RNA was extracted from a 286 single polyp of each colony using a RNeasy kit (Qiagen Inc., Valencia, CA, USA) according to 287 the manufacturer's instructions (for full details, see Supporting Methods). Approximately $1 \mu \mathrm{g}$ of RNA was used to construct a cDNA library for each sample using the Illumina TruSeq RNA v2 Kit (Illumina, San Diego, CA, USA) (see Supporting Methods). of Utah (Salt Lake City, Utah, USA) and samples were quantified using a Bioanalyzer (Agilent,

292 Santa Clara, CA, USA) (see Supporting Methods). We assembled the first de novo transcriptome 293 of $A$. calycularis with samples collected from Ischia. The following programs and scripts were run 294 on Stanford University's Sherlock cluster and all scripts used in this pipeline 295 (https://github.com/bethsheets/Astroides transcriptomics) along with a general guide are available 296 on GitHub (doi:10.5281/zenodo.2580291). Four population-specific de novo assemblies were 297 generated using three individuals per population for each population in the program Trinity-2.8.4 298 (see Supporting Methods). Prior trials mapping to available corallimorpharian genomes produced 299 incomplete assemblies. Therefore, assembled contigs were validated to be included in the 
assembly by filtering for only metazoan matches found in the combined UniProt's Swiss-Prot and TrEMBL databases using BLASTX in the BLAST+ toolkit (see Supporting Methods). Matches were considered significant at values of $\leq 1 \times 10^{-3}$ and the top hit for each contig was kept for assembly filtering and annotation. Transcriptome completeness was assessed using BUSCO v3 (see Supporting Methods) against the metazoan (obd9) set. BUSCO analyses revealed that the final combined transcriptome was 97\% complete (949 complete BUSCOs out of 978 searched: 366 complete single-copy, 583 complete and duplicated; 12 fragmented, and 17 missing). For the 41 individuals used for population analyses, the average overall mapping rates for each population were as follows: Vent-Grotta Mago 79\% (range 71.91 - 85.28), Ambient 1- Punta Vico 80\% (range 65 - 84.74), Ambient 2- Sant' Angelo- 80.26\% (range 71.91 - 85.28). After filtering, we detected 46,784 biallelic SNPs among the vent and two ambient populations.

\subsubsection{Mapping and SNP detection}

For all 41 samples, raw paired- and single-end sequence files were mapped to the de novo assembly using HISAT2 (see Supporting Methods) with the very-sensitive setting. Duplicate reads due to PCR were removed with Picard tools (http://broadinstitute.github.io/picard/) MarkDuplicates using the lenient validation stringency. Overall mapping rates were compared among populations to assess whether certain populations were preferentially mapping to the de novo assembly. Transcriptome-derived single nucleotide polymorphisms (SNPs) were called on all individuals using SAMtools mpileup and BCFtools (for filter settings, see Supporting Methods).

\subsubsection{Identifying SNP candidates for environmental selection in high $\mathrm{CO}_{2}$ conditions and} enrichment analysis

We identified potential outlier SNPs related to the $\mathrm{CO}_{2}$ vent location. We calculated pairwise Fst estimates (Vent - Ambient 1, Vent - Ambient 2, Ambient 1 - Ambient 2) per locus using the basic 

stats function with HIERFSTAT package in R (see Statistical analyses). We used these

324 estimates to compare the genetic distance for each SNP between the three populations

$325\left[F_{S T}\left(\right.\right.$ Vent-A1) $+F_{S T}\left(\right.$ Vent-A2))/F $\left.F_{S T}(A 1-A 2)\right]$. To identify potential outlier SNPS related to 326 the $\mathrm{CO}_{2}$ vent location, we compared the genetic distance for each SNP for the population

327 comparisons including Grotta Mago to the genetic distance between the ambient

328 populations $A 1$ and $A 2\left[F_{S T}(V e n t-A 1)+F_{S T}\left(\right.\right.$ Vent-A2))/ $\left.F_{S T}(A 1-A 2)\right]$. SNPs with values over

2 showed an excess of genetic differentiation in the $\mathrm{CO}_{2}$ Vent compared to the other ambient $\mathrm{pH}$ populations. Using the transcriptome assembly annotations, we searched for enrichment patterns in the contigs holding these candidate SNPs by using their UniProt identifiers (https://www.uniprot.org/) in a

Gene

Ontology

(GO) search (http://geneontology.org/).

\subsection{Statistical analyses and data visualization}

Environmental data analyses: Temperature, $\mathrm{pH}_{\mathrm{T}}$, SeaFET sensor calibration, carbonate chemistry and figures were performed using the R packages: seacarb v3.2.12 and ggplot2 v3.1.1 (see

337 Supporting Methods for R package references). Carbonate system parameter figures in the vent 338 system were created with Ocean Data View software (version 5.1.2, http://odv.awi.de). Biological surveys: A linear mixed model was used to test for differences in \% cover (logit transformation) as a function of site (fixed factor, 3 levels), depth (fixed factor, 4 levels) and quadrat as a random 
341 effect. Chi-square contingency tables were used to compare the size-frequency distributions 342 among sites, as well as the frequency of encrusting and massive forms. Kolmogorov-Smirnov two343 sample tests were used to determine whether there were significant differences in necrosis between 344 the $\mathrm{CO}_{2}$ vent and ambient $\mathrm{pH}$ sites. These analyses were computed using lme4 v1.1.21 package 345 implemented in R. Skeletal characteristics and growth: Relationships between biometrical and 346 skeletal parameters were calculated using the power function model. Pearson's correlation 347 coefficients were calculated for the relationships among biometric and skeletal parameters at both 348 colony and polyp levels. Spearman's rank correlation coefficient was used to calculate the 349 significance of the correlations between colony biometric and skeletal parameters and $\mathrm{pH}_{\mathrm{T}}$. ANOVA was used to test \% cenosarc (with arcsin transformation), mean mass, polyp number, 351 bulk density, linear extension rate, calcification rate, and porosity of the colonies and mean length 352 of corallites among sites. We used the non-parametric Kruskal-Wallis test for differences in means 353 for data that did not meet the assumption for normality and equal variance. Kruskal-Wallis tests 354 were applied to mean area, length, width, micro-density of colonies, corallite mean age, polyp 355 linear extension rate, net calcification rate, and length of central and all corallites. These analyses 356 were computed using IBM SPSS Statistics 12.0 (IBM Corporation). The Von Bertalanffy growth 357 model and confidence intervals (CI) were estimated through a regression analysis by least squares 358 procedure using raw data of corallite length and age (measured by computerized tomography) (see 359 Supporting Methods). These analyses were carried out in the software MATLAB R2012a 360 (MathWorks, Natick, USA). Population genetics: Population genetic analyses of SNPs, Weir and 361 Cockerham's pairwise $\mathrm{F}_{\mathrm{ST}}$ estimates among populations, and the heatmap of divergent SNP 362 genotypes were conducted in the R-based program HIERFSTAT v4.22 and ComplexHeatmap 363 v2.4.2, respectively. 
364

365

366

367

368

369

370

371

372

\section{RESULTS}

\subsection{Carbonate Chemistry Associated with the $\mathrm{CO}_{2}$ vent system in the Grotta del Mago' cave}

The $\mathrm{CO}_{2}$ vent system occurs at a $5 \mathrm{~m}$ depth inside the main chamber of the cave Grotta del Mago with approximately 5 vents $\mathrm{m}^{-2}$ (Figure 1) and do not elevate temperature (Table1, Figure S1, Table S1). The carbonate chemistry derived from discrete water samples and in situ monitoring of seawater $\mathrm{pH}_{\mathrm{T}}\left(\mathrm{pH}\right.$ on the total scale) delineated a $\mathrm{pH}_{\mathrm{T}}$ gradient from $4 \mathrm{~m}$ to $2 \mathrm{~m}$ depth caused by the distance from the bubbling of $\mathrm{CO}_{2}$ gas from the seafloor $\left(92-95 \% \mathrm{CO}_{2}\right.$, with undetectable levels of sulfur gas $<0.0002 \%$, see Supporting Note 1) (Figure 1, Table 1). pH sensors revealed reductions in mean $\mathrm{pH}_{\mathrm{T}}$ at each depth associated with increased temporal variability in $\mathrm{pH}_{\mathrm{T}}($ Figure 1, Table 1, Figure $\mathrm{S} 5$, Table S5). Mean $\mathrm{pH}_{\mathrm{T}}$ were: 7.65 to 7.88 at $2 \mathrm{~m} ; 7.62$ to 7.74 at $3 \mathrm{~m}$, and 7.60 to 7.60 at $4 \mathrm{~m}$, respectively (see Table 1 and Table $\mathrm{S} 5$ for detailed $\mathrm{pH}$ statistics). At $2 \mathrm{~m}$ depth, $14 \%$ and $56 \%$ of the $\mathrm{pH}_{\mathrm{T}}$ measurements were below 7.8 (projected average global sea surface $\mathrm{pH}$ value for the year 2100 with the high emission scenarios RCP8.5) (Gattuso et al., 2015) in June and September, respectively (Table S5). The percentage rose to $34 \%$ and $61 \%$ at $3 \mathrm{~m}$ depth, and $55 \%$ and $66 \%$ at $4 \mathrm{~m}$ depth, in June and September, respectively (Table S5). This pattern of depthdependent low $\mathrm{pH}_{\mathrm{T}}$ was also manifested as extreme $\mathrm{pH}$ events (defined as the $\mathrm{pH}$ value of 0.4 units less than the mean $\mathrm{pH}$ for each depth) that increased in number and duration with depth (Table S6). Mean $\mathrm{pH}_{\mathrm{T}}$ and variability were influenced by temperature stratification in June and September (Figure 1, Figures S5-S6). This is because during periods of stratification, and hence reduced vertical mixing (Turner, 1973), the input of $\mathrm{CO}_{2}$ is likely to be primarily confined to the lower part of the water column, leading to lower $\mathrm{pH}$ values near bed than when the water column is well mixed. The mean temperature difference between $2 \mathrm{~m}$ and $4 \mathrm{~m}$ in June was $0.25{ }^{\circ} \mathrm{C}$, whereas the mean temperature difference was only $0.02{ }^{\circ} \mathrm{C}$ in September (Figure S6). In September, reductions 
387 in seawater $\mathrm{pH}_{\mathrm{T}}$ were driven by increased dissolved inorganic carbon concentrations $\left(\mathrm{C}_{\mathrm{T}}\right)$ and

higher $p \mathrm{CO}_{2}$ concentrations at relatively constant total alkalinities $\left(\mathrm{A}_{\mathrm{T}}\right)$ and temperatures across depths (Table 1, Figure S5). Mean $p \mathrm{CO}_{2}$ ranged from $2905 \pm 1664 \mu \mathrm{atm}$ at $2 \mathrm{~m}$, to $3146 \pm 1928$ $\mu$ atm at $3 \mathrm{~m}$, to $3192 \pm 1806 \mu \mathrm{atm}$ at $4 \mathrm{~m}$ depth, and aragonite saturation state $(\Omega \mathrm{a})$ ranged from $1.10 \pm 0.4$ at $2 \mathrm{~m}$, to $1.05 \pm 0.4$ at $3 \mathrm{~m}$, and to $1.02 \pm 0.4$ at $4 \mathrm{~m}$ depth (Table 1). In contrast, in June, the vent site was characterized by an increase in temperature along the water column (from $\sim 18.5$ ${ }^{\circ} \mathrm{C}$ to $\sim 25^{\circ} \mathrm{C}$ ), which created greater difference across the three depths in terms of $\mathrm{pH}_{\mathrm{T}}$ and associated carbonate chemistry parameters, particularly for the $\mathrm{CO}_{2}$ concentrations (from $1531 \pm$ $627 \mu \mathrm{atm}$ at $2 \mathrm{~m}$, to $2082 \pm 1502 \mu \mathrm{atm}$ at $3 \mathrm{~m}$, and $2812 \pm 2310 \mu \mathrm{atm}$ at $4 \mathrm{~m}$ depth) and $\Omega \mathrm{a}$ (from $1.44 \pm 0.27$ at $2 \mathrm{~m}$, to $1.23 \pm 0.35$ at $3 \mathrm{~m}$, to $1.05 \pm 0.42$ at $4 \mathrm{~m} \mathrm{depth}$ ) (Table 1 , Figure S5). At the two ambient $\mathrm{pH}$ sites, the mean $\mathrm{pH}_{\mathrm{T}}$ ranged from 7.97 to 8.05 units, $p \mathrm{CO}_{2}$ from $322 \pm 34$ to $586 \pm$ $76 \mu$ atm, and $\Omega$ a from $3.54 \pm 0.23$ to $3.86 \pm 0.23$ (Table 1).

\subsection{Cover, population structure, and morphology of $A$. calycularis}

The $\mathrm{CO}_{2}$ vent population was characterized by small colonies ( $90 \%$ colonies had up to 10 polyps) and no large colonies of more than 20 polyps (class V) with massive morphology were found (Figure 2, Figure S7). Larger colonies (i.e. > 16 polyps, size classes IV and V) were only found in the two reference areas (percentage of larger size classes ranged from $13 \%$ in $\mathrm{A} 1$ to $16 \%$ in $\mathrm{A} 2$ ), which differed significantly among the $\mathrm{CO}_{2}$ vent site $\left(\chi^{2}=91.9, \mathrm{df}=8, \mathrm{p}<0.0001\right)$. Additionally, necrosis was significantly higher at the $\mathrm{CO}_{2}$ vent site $(13 \pm 4 \%)$ than the reference areas (both $<0.5 \%, \mathrm{D}=0.56, \mathrm{p}<0.0001)$. A. calycularis' cover at the $\mathrm{CO}_{2}$ vent site decreased from $50 \%$ at $1 \mathrm{~m}$ depth, to $30 \%$ at $2 \mathrm{~m}, 9 \%$ at $3 \mathrm{~m}$, and $1 \%$ at $4 \mathrm{~m}$ depth, as seawater $\mathrm{pH}_{\mathrm{T}}$ also declined (Figure $\mathrm{S} 7$ ). This decline in coral cover was also observed in Ambient 1 (also a cave, from 69\% at $1 \mathrm{~m}$ to $14 \%$ 
409 at $3 \mathrm{~m}$ ) but not in Ambient 2 (overhang, from $72 \%$ at $1 \mathrm{~m}$ to $62 \%$ at $3 \mathrm{~m} ; \mathrm{F}=14.1, \mathrm{df}=11,55$;

$410 \mathrm{p}<0.001)($ Figure S7).

$411 \quad 3.3$ Coenosarc, skeletal parameters and growth

412 Percentage of coenosarc (the living tissue connecting the polyps) significantly decreased between 413 ambient $\mathrm{pH}$ sites ( 87 and $70 \%$ ) and the $\mathrm{CO}_{2}$ vent (28 and 14\%) (Figure 2, $\mathrm{p}<0.0001$ ). Mean colony 414 area decreased by $\sim 80-71 \%$ and mean polyp number by $\sim 27-18 \%$ at the Vent deep compared 415 to ambient $\mathrm{pH}$ sites $(\mathrm{p}<0.001)$ (Figure $3 \mathrm{~A})$. The skeletal parameters that characterize the 416 architecture of colonies showed different patterns in relation to $\mathrm{pH}$ (Figure 3A-B, Figures S8-S9).

417 Bulk density (ratio dry mass to bulk volume) and micro-density (ratio of dry mass to matrix 418 volume) increased at low $\mathrm{pH}$, while porosity (ratio pore volume to bulk volume; see Methods) 419 decreased at low $\mathrm{pH}\left(\mathrm{p}<0.001\right.$; Figure 3A-B). Colonies at the $\mathrm{CO}_{2}$ vent deep presented higher 420 bulk density $(\sim+27 \%)$ and micro-density $(\sim+7 \%)$ and lower porosity $(\sim-28 \%)$ compared to 421 colonies from the ambient $\mathrm{pH}$ sites $(\mathrm{p}<0.001)$ (Figure 3A-B, Figure S9).

422 Growth parameters of $A$. calycularis differed significantly between the $\mathrm{CO}_{2}$ vent site and ambient $423 \mathrm{pH}$ sites (Figure 3B, Figure 4, Figure S10, Table S7). Mean polyp growth rate decreased 424 exponentially with age at all sites (Figure S10). Young individuals (1-3 years old) grew relatively 425 rapidly $\left(>2 \mathrm{~mm} \mathrm{yr}^{-1}\right)$, but, as they aged, their skeletal growth rate decreased $\left(<1.3 \mathrm{~mm} \mathrm{yr}^{-1}\right.$ at $8-$ 42610 years old) (Figure 4, Tables S7-S8). A trend toward higher linear extension and net calcification 427 rate was observed at low $\mathrm{pH}$ at the polyp level (Figure 3B, Table S7). Polyp net calcification rate 428 ranged from $3.95 \mathrm{mg} \mathrm{mm}^{-2} \mathrm{yr}^{-1}$ at Vent deep, to $3.04 \mathrm{mg} \mathrm{mm}^{-2} \mathrm{yr}^{-1}$ at Vent shallow, to $2.39 \mathrm{mg}$ $429 \mathrm{~mm}^{-2} \mathrm{yr}^{-1}$ and $2.06 \mathrm{mg} \mathrm{mm}^{-2} \mathrm{yr}^{-1}$ at ambient $\mathrm{pH}$ sites (Table S7). This indicates that net calcification 430 rates increased approximately by $48 \%-93 \%$ from the more acidified (Vent deep) to the less 431 acidified (Vent shallow) to the non-acidified (ambient $\mathrm{pH}$ ) locations at polyp level. Linear 
432 extension and net calcification rates at colony level were homogenous in ambient $\mathrm{pH}$ and acidified

433 conditions (Figure 3B, Table S7).

$434 \quad 3.4$ Transcriptome assembly and population genomics

435 The A. calycularis transcriptome composed of 12 colonies contained 113,351 contigs with an N50

436 of 2,285 (range $501-38,179$ ). Based on 46,784 SNPs in 41 individuals, PCA analysis revealed

437 strong clustering by population (Figure 5). The vent population in Grotta Mago was most distinct

438 along PCA axis 1, but overlapped with Ambient1 (PV) along axis 2. Pairwise $\mathrm{F}_{\mathrm{ST}}$ measurements

439 also support strong population structure within each of the three locations: $\mathrm{CO}_{2}$ vent (Grotta Mago)

$440-$ Ambient $1($ Punta Vico $)=0.034, \mathrm{CO}_{2}$ vent $($ Grotta Mago $)-$ Ambient $2($ Sant'Angelo $)=0.026$,

441 Ambient 1 (Punta Vico) - Ambient 2 (Sant'Angelo) $=0.024$. SNPs with values over 2 show an

442 excess of genetic differentiation in GM compared to the other populations. There were 334 loci

443 with an excess $\mathrm{F}_{\mathrm{ST}}$ ratio of 10 or more, out of 2246 loci in our data set with known molecular

444 function. An analysis of the 402 unique molecular function Gene Ontology (GO) terms associated

445 with these loci showed there to be three significant enrichment classes (Table S9): calcium ion

446 binding (12 loci, padj $\left.=7 \times 10^{-23}\right)$, catalytic activity $\left(4\right.$ loci, padj $\left.=2 \times 10^{-9}\right)$, and

447 oxidoreductase action (12 loci, padj $=0.05)$.

448 Calcium ion loci include calmodulin, calcineurin, calnexin, calcium-binding proteins in the 449 sarcoplasmic reticulum, and a set of two poorly characterized proteins with calcium binding motifs 450 (Contigs 3436 and 7780). These proteins are EF-hand calcium-binding protein and C-type lectin 451 calcium-binding in a hmmer database search (https:/www.ebi.ac.uk/Tools/hmmer/). Because 
452 calcium ion control is particularly central to calcification in scleractinians, we examined the 77

453 SNPs from the thirteen calcium-related loci for patterns across populations (Figure 6). As

454 expected, the Grotta Mago population had highly divergent SNP genotypes at these loci (average

455 minor allele frequency difference of 0.24 ), but these genes also showed a strong degree of

456 linkage among SNP genotypes within a single gene often across 1000s of base pairs (Figure 6).

457 Such multi-SNP haplotypes are rare in our data set yet occur in 8 of 10 high excess, calcium ion

458 loci with multiple SNPs.

459 Given the strong differences in calcium management suggested by excess differentiation

460 of calcium ion genes in Grotta Mago, we queried our transcriptome SNP data base for

461 other genes potentially involved in calcification. In corals, calcification occurs in the

462 calicoblastic space through a combination of high calcium concentration and high $\mathrm{pH}$ (reviewed

463 in Drake et al., 2020). High $\mathrm{pH}$ is achieved through proton transport by specific calcium/proton 464 pumps, including the plasma membrane calcium ATPase (PMCA). There were no PMCA 465 polymorphisms in our data set, but the V-type ATPase proton pump (contig DN1551, SNPs 1701466 1805) showed six of seven SNPs with strong differentiation in Grotta Mago (excess 0.03 -28.8, 467 average 11.4, Figure 6). Minor allele frequencies differed by about a factor of 2 in Grotta Mago 468 compared to the other locations, and SNPs show strong linkage.

469 In addition to genes involved in calcium and $\mathrm{pH}$ regulation, we explored possible adaptation in 470 genes managing intracellular carbonate chemistry. Coral calcification depends on the delivery of $471 \mathrm{CO}_{2}$ to the calicoblastic layer where it is converted to carbonate ions (Cohen \& McConnaughey, 
472 2003). In A. calycularis, a plethora of carbonate related genes showed high differentiation and high

473 linkage in Grotta Mago, including carboxylases and transporters, but the most interesting is a

474 carbonic anhydrase (Contig 15508, 5 of 12 SNPs with excess Fst above 10, average=10.3).

475 Carbonic anhydrases convert highly diffusive $\mathrm{CO}_{2}$ into charged carbonate ions, localizing them in

476 the calicoblastic layer and regulating calcification (Chen, Gagnon, \& Adkins, 2018), though they

477 also play a role in $\mathrm{pH}$ regulation of non-calcifying coral cells (Bertucci et al., 2013).

478 4. DISCUSSION

479 This study contributes to increasing our understanding of how coral populations persist under 480 naturally high $\mathrm{pCO}_{2}$ environments - and therefore how they might cope under future ocean 481 acidification scenarios - and links trait-shifts with local variation in environmental parameters found 482 in this new $\mathrm{CO}_{2}$ vent system. Our results expand upon previous research on populations of corals 483 exposed to naturally elevated $p \mathrm{CO}_{2}$ (Crook, Cohen, Rebolledo-Vieyra, Hernandez, \& Paytan, 2013;

484 Enochs et al., 2015; Fabricius et al., 2011; Fantazzini et al., 2015), demonstrating unexpected shifts 485 in patterns of skeleton and growth of the azooxanthellate coral A. calycularis. Specifically, 486 colonies shift to a skeletal phenotype characterized by encrusting morphology, smaller size, 487 reduced coenosarc tissue, fewer polyps, and less porous and denser skeletons at low $\mathrm{pH}$. However, 488 while individual polyps calcified more (greater net calcification rates), calcification rate of whole 489 colonies were similar across sites. The resulting colony skeletons showed equal linear extension 490 at low and ambient $\mathrm{pH}$ conditions, while their polyp skeletons extended faster in acidified 491 conditions (Figure 7). Transcriptomic data revealed strong genetic differentiation among local 492 populations of this low-dispersal species. We found excess differentiation in the Grotta Mago 493 population for genes central to calcification, including genes for calcium management 
494 (calmodulin, calcium-binding proteins), $\mathrm{pH}$ regulation (V-type proton ATPase), and carbonate 495 localization (carbonic anhydrase).

496

497 Environmental variability in the $\mathrm{CO}_{2}$ vent system

498 The vent system exhibits high temporal variability in seawater $\mathrm{pH}$ due to varying $\mathrm{CO}_{2}$ venting 499 intensity from the seabed, mixing due to variations in stratification, and fundamental 500 thermodynamics processes fundamental to the carbonate system (Takeshita et al., 2015). The 501 carbonate chemistry and in situ monitoring of seawater $\mathrm{pH}$ delineated a $\mathrm{pH}$ gradient (from 4 to 2 $502 \mathrm{~m}$ depth) caused by the distance from the venting. This acidification gradient is important for the 503 colonies exposed to more (deep) or less (shallow) acidified conditions, as reflected by the 504 biological response of Astroides. The conditions in these zones are comparable with IPCC 505 projections for near future acidification scenarios (RCP2.6 and RCP8.5), which project a decrease 506 in surface $\mathrm{pH}$ from -0.14 to $-0.4 \mathrm{pH}$ units by 2100 relative to 1870 (Gattuso et al., 2015). $\mathrm{pH}$ and 507 its variability found in this study are comparable with the range of natural variation observed in 508 other $\mathrm{CO}_{2}$ vent systems, with fluctuations of $0.6,0.7$ and $0.5 \mathrm{pH}$ units in coral reefs (Agostini et 509 al., 2018), temperate reefs in Panarea (Prada et al., 2017) and in other $\mathrm{CO}_{2}$ vents in Ischia (Teixidó 510 et al., 2018), respectively. Likewise, Hofmann et al. (2011) reported pH fluctuations between 0.024 511 to $1.430 \mathrm{pH}$ units, in which $\mathrm{pH}$ measurements were taken from different locations, ranging from 512 polar to tropical, and open-ocean to coastal areas. Interestingly, as mean $\mathrm{pH}$ was reduced, its 513 variability and the percentage of $\mathrm{pH}_{\mathrm{T}}$ measurements registered below 7.8 units increased, when 514 seawater was uniformly warm. In contrast, in June when the water column was stratified, $\mathrm{pH}$ and 515 its variability near the bottom was similar to what was observed in September whereas, farther 
516 from the bottom, $\mathrm{pH}$ was higher and less variable. These results indicate that seawater stratification

517 may play a key role in controlling the temporal and depth patterns of $\mathrm{pH} / \mathrm{pCO}$.

519 Shifts in coral skeleton, growth, and coenosarc

520 Each scleractinian coral species may adopt different growth strategies in response to ocean 521 acidification. For example, investing calcification resources in bulk skeletal density by sacrificing 522 the rate of linear extension has been observed in Orbicella annularis (Carricart-Gavinet, 2007). In 523 contrast, investing calcification resources in linear extension rate at the expense of bulk density 524 has been reported for some Porites (Lough \& Barnes, 2000) and Dendrophyllidae species 525 (Goffredo et al., 2009). Both strategies may imply different ecological trade-offs for the coral: 526 investing in a denser skeleton results in greater resistance to mechanical stress, while increasing 527 linear extension rate may be advantageous for space competition and earlier sexual maturity 528 (Goffredo et al., 2009). Unexpectedly, A. calycularis revealed unusual patterns in the calcification 529 response to ocean acidification, such as higher bulk skeletal density and lower porosity while 530 maintaining colony linear extension rates and net calcification. This response is different to what 531 was previously shown in solitary corals (e.g. Balanophyllia europaea) growing in natural low pH 532 conditions, where a decrease of net calcification resulted from preserving linear extension (to reach 533 the polyp size of sexual maturity) at the expenses of lower bulk density (e.g. increased in skeletal 534 porosity resulting in more fragile skeletons) (Fantazzini et al., 2015). Tambutté et al.(2015) found 535 the same response of decreasing calcification and bulk skeletal density while linear extension of 536 skeleton remained unchanged in the tropical coral Stylophora pistillata subjected to low $\mathrm{pH}$ 537 conditions in laboratory. Mollica et al. (2018) modelled the skeletal growth to changes in seawater 538 chemistry and predicted declines in Porites skeletal density but no linear extension across global 
539 reefs, reflecting the large variability in the response of coral calcification to ocean acidification.

540 The authors suggested that under low-pH conditions, the increase in linear extension reflects the

541 elongation of calcium carbonate crystals at the site of calcification, while the increase in skeletal

542 density reflects the lateral thickening of calcified elements of coral skeleton (Mollica et al., 2018).

543 The unusual response of $A$. calycularis to acidification may reflect an overall maintenance of

544 energetic resources allocated to calcification at the level of the colonies, which extended at the

545 same rate but were composed by fewer polyps, thus partitioning the available energy for

546 calcification among fewer polyps (Swain et al., 2018). We can therefore reasonably assume that

547 nutrients levels, and potentially the zooplankton, did not differ among study sites (Supporting

548 Material Table S2). As a result, a single polyp would have more energetic resources available for

549 calcification than in ambient $\mathrm{pH}$ conditions, as indicated by their greater skeletal growth

550 parameters. This particular response may be possible in A. calycularis due to its colonial nature.

551 We hypothesize that in order to maintain the calcification rate at the colony level, colonies tend to 552 decrease their number of polyps, but in turn, their few polyps extend their skeleton faster to reach

553 the size of sexual maturity. No asexual division (fragmentation) has been observed over 5 years in

554 A. calycularis in the three study sites, suggesting that this strategy of reproduction is not common.

555 A. calycularis exhibited at the vent site a morphological shift to encrusting and smaller colonies,

556 with less porous, and potentially more robust corallite skeletal architecture.

557 While individuals from the vents were composed of corallites with higher skeletal density, this

558 was less evident at the colony level. While skeletal integrity was not strictly quantified, 559 observations at the vent site showed that the colonies were more fragile and lost their integrity 560 more readily, suggesting that the section of the skeleton located between the polyps (coenosteum)

561 was either less calcified and/or more prone to dissolution. This could be the result of thinner or 
562 absent coenosarc (the tissue covering the coenosteum) found in the colonies at the $\mathrm{CO}_{2}$ vent.

563 Contrasting responses between skeletal parts that either are or are not protected by living tissues

564 has already been reported for corals (Hennige et al., 2015; Ries, 2011; Rodolfo-Metalpa et al.,

565 2011). This loss of coenosarc could indicate the beginning of a further shift from colonial forms

566 towards solitary polyps to ensure survivorship, as has occurred throughout the history of

567 scleractinian coral evolution and in laboratory conditions (Fine \& Tchernov, 2007; Kvitt et al.,

568 2015). Interestingly, it was recently shown that following a heatwave and a bleaching event, the

569 Mediterranean coral Cladocora caespitosa suffered from apparent mortality but its tissues actually

570 retracted inside the individual corallites before rejuvenescence occurred a few years later (Kersting

571 \& Linares, 2019). Here, we hypothesize that a similar, but less extreme phenomenon occurred with

572 the corals reducing their coenosarc in response to low $\mathrm{pH}$. A reduction in tissue thickness can have

573 implications for calcification because the precipitation of calcium carbonate occurs in the

574 calcifying fluid that is a medium semi-isolated from the external seawater by the overlying coral

575 tissues. To promote calcification, corals have the ability to upregulate $\mathrm{pH}$ and $\mathrm{C}_{\mathrm{T}}$ (dissolved

576 inorganic carbon) concentrations in the calcifying fluid (Comeau, Cornwall, \& Mcculloch, 2017),

577 a capacity that is reduced under ocean acidification (McCulloch, Falter, Trotter, \& Montagna,

578 2012). Here reduced calcification between the polyps was likely due to a reduction of coral ability

579 to maintain optimal carbonate chemistry conditions in the calcifying fluid between the polyps. This

580 could have been the result of natural spatial heterogeneity sensitivity of colonies to acidification

581 (Holcomb et al., 2014). In addition to reduced calcification, thinning or disappearing of the tissues

582 likely led to local dissolution because exposed skeletons are more prone to dissolution (Ries,

583 2011). As a result of reduced calcification and dissolution of the coenosteum, colonies at the vent

584 site were weaker and smaller despite heavily calcified corallites. 
Genomics of differentiation of corals at the $\mathrm{CO}_{2}$ vent system

587 Our results show strong genetic differentiation of all three A. calycularis populations ( $\mathrm{F}_{\mathrm{ST}}$ 588 averaging $0.024-0.034$ ), with over $5000 \mathrm{SNPs}$ showing $\mathrm{F}_{\mathrm{ST}}>0.10$. A previous genetic study of $A$. 589 calycularis using microsatellites also found significant genetic differentiation at km-scale 590 distances, likely a reflection of this species limited dispersal capabilities (Casado-Amezúa et al., 591 2012). These data showed strong linkage among SNPs across 1000s of bp within genes and strong 592 linkage across different genes. These patterns could be generated by selective sweeps acting on a 593 small number of founder colonies, but because linkage among genes and SNPs occurs among 594 ambient $\mathrm{pH}$ (Ambient 1 and Ambient 2) individuals as well as Vent corals. These linkages were 595 probably not due to recent selection at the $\mathrm{CO}_{2}$ vent site alone but reflect the underlying 596 architecture of adaptation. A. calycularis is a warm-water coral whose distribution range is 597 currently expanding northward (Bianchi, 2007), where Ischia belongs to the north-east margin of 598 the confirmed distribution. As a result, it is also likely that selection is acting at the Ambient 1 and 5992 sites compared to more southerly populations. Disentangling the ways in which selection at high $600 \mathrm{CO}_{2}$ locations combines with selection at higher temperatures may be particularly important in 601 future ocean conditions. The matrix of genetically distinct populations of A. calycularis 602 experiencing a variety of selection regimes for heat and $\mathrm{CO}_{2}$ may be a powerful setting for this 603 future work.

604 The most highly differentiated genes in the vent site population, Grotta Mago, are 605 annotated for calcium regulation, proton pumping, and inorganic carbon regulation. It is 606 possible that they are differentiated in Grotta Mago for reasons other than selection on 
607 calcification in the presence of high $\mathrm{CO}_{2}$. However, the strong shift in alleles at these loci 608 and the linkage among those differentiated SNPs provides a strong set of hypotheses for

609 the way selection might act to favor coral calcification at low $\mathrm{pH}$.

610 Two loci of calmodulin were highly differentiated in Grotta Mago, with linked SNPs in our

611 data set. Calcium transporter genes are thought to be important in delivering calcium to

612 the calicoblastic space (Allemand, Tambutté, Zoccola, \& Tambutté, 2011). Though the

613 precise mechanism is not known, calmodulin along with calbindin and calreticulin are

614 hypothesized to play a role in managing calcium levels and can be sensitive to $\mathrm{pH}$

615 (Allemand et al., 2011). For example, Kaniewska et al. (2012) showed 8-fold down

616 regulation of calmodulin in a $\mathrm{CO}_{2}$-treated reef building coral. An increase in calcium at the

617 site of calcification has been shown as a mean to alleviate the negative effect of low $\mathrm{pH}$ in some

618 corals (Decarlo, Comeau, Cornwall, \& McCulloch, 2018). Our data also showed excess

619 differentiation in genes that depend on calcium concentrations for their function, such as

620 calineurin, calnexin and the sarcoplasmic reticulum histidine-rich calcium-binding protein,

621 which are thought to play a role in calcium homeostasis. 
622 Intracellular and vacuolar $\mathrm{H}+$ concentrations are central to coral calcification by controlling

$623 \mathrm{pH}$ of the calcifying fluid and the calicoblastic and gastrodermal cells. The V-type ATPase

624 proton pump is localized in the symbiosomes of corals that contain intracellular symbionts

625 (Tresguerres, 2016), but is also highly expressed in non-symbiotic gastroderm of symbiont-free tips of quickly calcifying corals, suggesting a role in calcification in the

627 absence of symbionts (Perez, 2015). In particular, the protein VHA (V-type proton ATPase) is differentially regulated in corals exposed to low $\mathrm{pH}$, being downregulated more than four fold in experiments on the reef building coral Acropora millepora

630 (Kaniewska et al., 2012). The population of $A$. calicularis in Grotta Mago showed strong

631 differentiation at 6 SNPs across a 100 bp region of this gene.

$632 \mathrm{CO}_{2}$ diffuses very quickly through cells, and is hard to localize in cell regions that need it

633 for photosynthesis or calcification. Carbonic anhydrase catalyzes the reaction to convert

$634 \mathrm{CO}_{2}$ to carbonate ions that diffuse much less quickly. As a consequence, carbonic 635 anhydrase is central to calcification in many marine species. In fact, Zebral et al. (2019)

636 suggest use of it as a biomarker to monitor effects of acidification. In corals, carbonic

637 anhydrase is thought to favor carbonate ion concentration in the calicoblastic space and 
638 in symbiosomes through conversion of $\mathrm{CO}_{2}$ (Chen et al., 2018; Zoccola et al., 2016).

639 However, low-pH experiments on a deep water coral (Lophelia pertusa) did not find strong

640 shifts in carbonic anhydrase activity, nor did an examination of carbonic anhydrase in

641 polychaete worms from the Ischia $\mathrm{CO}_{2}$ vents (Del Pasqua, Gambi, Caricato, Lionetto, \&

642 Giangrande, 2019). Experiments on reef building corals have shown mixed results

643 (Kurihara, Takahashi, Reyes-Bermudez, \& Hidaka, 2018). We found strong differentiation

644 of one carbonic anhydrase locus in Grotta Mago. An average shift in minor allele

645 frequency from 0.14 to 0.50 in six linked SNPs may signal differential activity of this gene

646 in some functionally important way. These SNPs appear to be downstream of the

647 carbonic anhydrase coding region and if they play a role it may be as allele-specific

648 regulators of expression. These allele differences may be a good tool to understand the

649 role of carbonic anhydrase in reaction to high $\mathrm{CO}_{2}$.

650 In conclusion, our study demonstrates that the natural population of the azooxanthellate coral $A$.

651 calycularis living near the $\mathrm{CO}_{2}$ vent system shows variable responses in terms of skeleton and

652 growth patterns that result in a shift in phenotypic and ecological traits. We have shown that these

653 variable responses at the polyp and colony level allow this coral to cope with low and variable $\mathrm{pH}$

654 in the long term by re-allocating energy investments between individual and colony growth as well 
655 as mineralogical characteristics. Transcriptomic data revealed strong genetic differentiation among 656 local populations with several candidate loci and linkage blocks under selection. In addition, we 657 found excess differentiation in the $\mathrm{CO}_{2}$ vent population for genes central to calcification, including 658 genes for calcium management (calmodulin, calcium-binding proteins), $\mathrm{pH}$ regulation (V-type 659 proton ATPase), and inorganic carbon regulation (carbonic anhydrase). These patterns highlight 660 both the $\mathrm{CO}_{2}$ vents as well as the fringes of this species' expansion as potential drivers of 661 adaptation.

662 
663

664

665

666

667

668

669

670

671

672

673

674

675

676

677

678

679

680

681

682

683

684

\section{REFERENCES}

Agostini, S., Harvey, B. P., Wada, S., Kon, K., Milazzo, M., Inaba, K., \& Hall-Spencer, J. M. (2018). Ocean acidification drives community shifts towards simplified non-calcified habitats in a subtropical - temperate transition zone. Scientific Reports, 8, 11354.

https://doi.org/10.1038/s41598-018-29251-7

Allemand, D., Tambutté, É., Zoccola, D., \& Tambutté, S. (2011). Coral calcification, cells to reefs. In Z. Dubinsky \& N. Stambler (Eds.), Coral Reefs: An Ecosystem in Transition (pp. 1552). Springer. https://doi.org/10.1007/978-94-007-0114-4

Bennett, S., Duarte, C. M., Marba, N., \& Wernberg, T. (2019). Integrating within-species variation in thermal physiology into climate change ecology. Philosophical Transactions of the Royal Society B, 374, 20180550.

Bertucci, A., Moya, A., Tambutté, S., Allemand, D., Supuran, C. T., \& Zoccola, D. (2013).

Carbonic anhydrases in anthozoan corals - A review. Bioorganic and Medicinal Chemistry, 21(6), 1437-1450. https://doi.org/10.1016/j.bmc.2012.10.024

Bianchi, C. N. (2007). Biodiversity issues for the forthcoming tropical Mediterranean Sea. Hydrobiologia, 580, 7-21. https://doi.org/10.1007/s10750-006-0469-5

Bozinovic, F., Calosi, P., \& Spicer, J. I. (2011). Physiological correlates of geographic range in animals. Annual Review of Ecology, Evolution, and Systematics, 42, 155-179. https://doi.org/10.1146/annurev-ecolsys-102710-145055

Brandl, S. J., Rasher, D. B., Côté, I. M., Casey, J. M., Darling, E. S., Lefcheck, J. S., \& Duffy, J. E. (2019). Coral reef ecosystem functioning: eight core processes and the role of biodiversity. Frontiers in Ecology and the Environment, 17, 445-454. https://doi.org/10.1002/fee.2088 
685 Camp, E. F., Schoepf, V., Mumby, P. J., Hardtke, L. A., Rodolfo-Metalpa, R., Smith, D. J., \& 686 Suggett, D. J. (2018). The future of coral reefs subject to rapid climate change: lessons from 687 natural extreme environments. Frontiers in Marine Science, 5, 4.

688 https://doi.org/10.3389/fmars.2018.00004

689 Carricart-Gavinet, J. P. (2007). Annual density banding in massive coral skeletons: result of 690 growth strategies to inhabit reefs with high microborers' activity? Marine Biology, 153, 1-5.

691 Casado-Amezúa, P., Goffredo, S., Templado, J., \& Machordom, A. (2012). Genetic assessment 692 of population structure and connectivity in the threatened Mediterranean coral Astroides 693 calycularis (Scleractinia, Dendrophylliidae) at different spatial scales. Molecular Ecology, 21, 694 3671-3685. https://doi.org/10.1111/j.1365-294X.2012.05655.X

Chan, N. C. S., \& Connolly, S. R. (2013). Sensitivity of coral calcification to ocean acidification: a meta-analysis. Global Change Biology, 19(1), 282-290.

697 https://doi.org/doi:10.1111/gcb.12011

698 Chen, S., Gagnon, A. C., \& Adkins, J. F. (2018). Carbonic anhydrase, coral calcification and a 699 new model of stable isotope vital effects. Geochimica et Cosmochimica Acta, 236, 179-197. 700 https://doi.org/10.1016/j.gca.2018.02.032

701 Cinelli, F., Fresi, E., Mazzella, L., Pansini, M., Pronzato, R., \& Svoboda, A. (1977). Distribution 702 of benthic phyto- and zoocoenoses along a light gradient in a superficial marine cave. In B. F. 703 Keegan, P. O. O’Ceidig, \& P. J. Boaden (Eds.), Biology of Benthic organisms (pp. 173-183). 704 Pergamon Press, Oxford.

705 Cohen, A. L., \& McConnaughey, T. A. (2003). Geochemical Perspectives on Coral 706 Mineralization. In P. M. Dove, S. Weiner, \& J. J. DeYoreo (Eds.), Biomineralization (Vol. 54, 

pp. 151-187). The Mineralogical Society of America, Washington, DC. https://doi.org/10.2113/0540151

709

710

711

712

713

714

715

716

717

718

719

720

721

722

723

724

725

726

727

728

Comeau, S., Cornwall, C. E., \& Mcculloch, M. T. (2017). Decoupling between the response of coral calcifying fluid $\mathrm{pH}$ and calcification to ocean acidification. Scientific Reports, 7, 7573. https://doi.org/10.1038/s41598-017-08003-z

Crook, E. D., Cohen, A. L., Rebolledo-Vieyra, M., Hernandez, L., \& Paytan, A. (2013). Reduced calcification and lack of acclimatization by coral colonies growing in areas of persistent natural acidification. Proceedings of the National Academy of Sciences of the United States of America, 110(27), 11044-11049. https://doi.org/10.1073/pnas.1301589110

Dappiano, M., \& Gambi, M. C. (2004). New data on occurrence of thermophile Scleractinia (Cnidaria, Anthozoa) in the Phlaegrean Island (Ischia, Procida, Vivara, Gulf of Naples), with special attention to Astroides calycularis. Biogeographia - The Journal of Integrative Biogeography, 25, 1-15. https://doi.org/10.21426/B6110042

Darling, E. S., Alvarez-Filip, L., Oliver, T. A., Mcclanahan, T. R., \& Côté, I. M. (2012). Evaluating life-history strategies of reef corals from species traits. Ecology Letters, 15(12), 1378-1386. https://doi.org/10.1111/j.1461-0248.2012.01861.x

Decarlo, T. M., Comeau, S., Cornwall, C. E., \& McCulloch, M. T. (2018). Coral resistance to ocean acidification linked to increased calcium at the site of calcification. Proceedings of the Royal Society B: Biological Sciences, 285(1878), 20180564.

https://doi.org/10.1098/rspb.2018.0564

Del Pasqua, M., Gambi, M. C., Caricato, R., Lionetto, M. G., \& Giangrande, A. (2019). Effects of short-term and long-term exposure to ocean acidification on carbonic anhydrase activity and 
729 morphometric characteristics in the invasive polychaete Branchiomma boholense (Annelida:

730 Sabellidae): A case-study from a $\mathrm{CO}_{2}$ vent system. Marine Environmental Research, 144, 203212. https://doi.org/10.1016/j.marenvres.2019.01.011

732

Doney, S. C., Fabry, V. J., Feely, R. A., \& Kleypas, J. A. (2009). Ocean Acidification: The Other $\mathrm{CO}_{2}$ Problem. Annual Review of Marine Science, 1(1), 169-192. https://doi.org/10.1146/annurev.marine.010908.163834

Drake, J. L., Mass, T., Stolarski, J., Von Euw, S., van de Schootbrugge, B., \& Falkowski, P. G. (2020). How corals made rocks through the ages. Global Change Biology, 26(1), 31-53.

737 https://doi.org/10.1111/gcb.14912

738

739

740

Enochs, I. C., Manzello, D. P., Donham, E. M., Kolodziej, G., Okano, R., Johnston, L., ... Price, N. N. (2015). Shift from coral to macroalgae dominance on a volcanically acidified reef. Nature Climate Change, 5, 1083-1088. https://doi.org/10.1038/nclimate2758

Fabricius, K. E., Langdon, C., Uthicke, S., Humphrey, C., Noonan, S., De 'ath, G., ... Lough, J. M. (2011). Losers and winners in coral reefs acclimatized to elevated carbon dioxide concentrations. Nature Climate Change, 1(6), 165-169. https://doi.org/10.1038/NCLIMATE1122

Fantazzini, P., Mengoli, S., Pasquini, L., Bortolotti, V., Brizi, L., Mariani, M., ... Goffredo, S. (2015). Gains and losses of coral skeletal porosity changes with ocean acidification acclimation. Nature Communications, 6, 7785. https://doi.org/10.1038/ncomms8785

Fine, M., \& Tchernov, D. (2007). Scleractinian coral species survive and recover from decalcification. Science, 315(5820), 1811. https://doi.org/10.1126/science.1137094 
750 Gattuso, J.-P., Magnan, A., Bille, R., Cheung, W. W. L., Howes, E. L., Joos, F., ... Turley, C.

751 (2015). Contrasting futures for ocean and society from different anthropogenic $\mathrm{CO}_{2}$ emissions 752 scenarios. Science, 349, aac4722. https://doi.org/10.1126/science.aac4722

753 Goffredo, S., Caroselli, E., Mattioli, G., Pignotti, E., Dubinsky, Z., \& Zaccanti, F. (2009).

754 Inferred level of calcification decreases along an increasing temperature gradient in a

755 Mediterranean endemic coral. Limnology and Oceangraphy, 54(3), 930-937.

756 Goffredo, S., Prada, F., Caroselli, E., Capaccioni, B., Zaccanti, F., Pasquini, L., ... Falini, G.

757 (2014). Biomineralization control related to population density under ocean acidification. Nature Climate Change, 4(7), 593-597. https://doi.org/10.1038/NCLIMATE2241 acidification. Nature, 454(7200), 96-99. https://doi.org/10.1038/nature07051 470, 479-485. https://doi.org/10.1038/nature09670 6(12), e28983. https://doi.org/10.1371/journal.pone.0028983 

M. (2014). Coral calcifying fluid pH dictates response to ocean acidification. Scientific Reports, 4, 5207. https://doi.org/10.1038/srep05207

773

774

775

776

777

778

779

780

781

782

783

784

785

786

787
Kaniewska, P., Campbell, P. R., Kline, D. I., Rodriguez-Lanetty, M., Miller, D. J., Dove, S., \& Hoegh-Guldberg, O. (2012). Major cellular and physiological impacts of ocean acidification on a reef building coral. PLOS ONE, 7(4), e34659. https://doi.org/10.1371/journal.pone.0034659

Kapsenberg, L., \& Cyronak, T. (2019). Ocean acidification refugia in variable environments. Global Change Biology, 00, 1-14. https://doi.org/10.1111/gcb.14730

Kersting, D. K., \& Linares, C. (2019). Living evidence of a fossil survival strategy raises hope for warming-affected corals. Science Advances, 5, eaax2950.

Kroeker, K. J., Bell, L. E., Donham, E. M., Hoshijima, U., Lummis, S., Toy, J. A., \& Norton, E. W. (2019). Ecological change in dynamic environments: Accounting for temporal environmental variability in studies of ocean change biology, 00, 1-14. https://doi.org/10.1111/gcb.14868

Kurihara, H., Takahashi, A., Reyes-Bermudez, A., \& Hidaka, M. (2018). Intraspecific variation in the response of the scleractinian coral Acropora digitifera to ocean acidification. Marine Biology, 165(2), 38. https://doi.org/10.1007/s00227-018-3295-1

Kvitt, H., Kramarsky-Winter, E., Maor-Landaw, K., Zandbank, K., Kushmaro, A., Rosenfeld, H., ... Tchernov, D. (2015). Breakdown of coral colonial form under reduced $\mathrm{pH}$ conditions is initiated in polyps and mediated through apoptosis. Proceedings of the National Academy of Sciences of the United States of America, 112(7), 2082-2086.

https://doi.org/10.1073/pnas.1419621112 
792 Lough, J. M., \& Barnes, D. J. (2000). Environmental controls on growth of the massive coral 793 Porites. Journal of Experimental Marine Biology and Ecology, 245, 225-243.

794 McCulloch, M., Falter, J., Trotter, J., \& Montagna, P. (2012). Coral resilience to ocean 795 acidification and global warming through $\mathrm{pH}$ up-regulation. Nature Climate Change, 2(8), 796 623-627. https://doi.org/10.1038/nclimate1473

797 Mollica, N. R., Guo, W., Cohen, A. L., Huang, K. F., Foster, G. L., Donald, H. K., \& Solow, A. 798 R. (2018). Ocean acidification affects coral growth by reducing skeletal density. Proceedings 799 of the National Academy of Sciences of the United States of America, 115(8), 1754-1759. 800 https://doi.org/10.1073/pnas.1712806115

801 Mouillot, D., Graham, N. A. J., Villéger, S., Mason, N. W. H., \& Bellwood, D. R. (2013). A 802 functional approach reveals community responses to disturbances. Trends in Ecology and 803 Evolution, 28(3), 167-177. https://doi.org/10.1016/j.tree.2012.10.004

804 Movilla, J., Calvo, E., Coma, R., Serrano, E., López-Sanz, À., \& Pelejero, C. (2016). Annual 805 response of two Mediterranean azooxanthellate temperate corals to low-pH and 806 high-temperature conditions. Marine Biology, 163, 135. https://doi.org/10.1007/s00227-016$807 \quad 2908-9$

808 Palumbi, S. R., Barshis, D. J., Traylor-Knowles, N., \& Bay, R. A. (2014). Mechanisms of reef 809 coral resistance to future climate change. Science, 344, 895-898.

810 https://doi.org/10.1126/science. 1251336

811 Perez, S. O. (2015). Characterization of sodium potassium -ATPase and vacuolar proton 812 ATPase in three coral species from two different clades. Thesis/dissertation. University of 813 California San Diego. Retrieved from https://escholarship.org/uc/item/0xp4r2hb 
814 Prada, F., Caroselli, E., Mengoli, S., Brizi, L., Fantazzini, P., Capaccioni, B., ... Goffredo, S. 815 (2017). Ocean warming and acidification synergistically increase coral mortality. Scientific 816 Reports, 7, 40842. https://doi.org/10.1038/srep40842

817 Ries, J. (2011). Acid ocean cover up. Nature Climate Change, 1, 294-295.

818 Ries, J. B. (2011). A physicochemical framework for interpreting the biological calcification 819 response to $\mathrm{CO}_{2}$-induced ocean acidification. Geochimica et Cosmochimica Acta, 75(14), 820 4053-4064. https://doi.org/10.1016/j.gca.2011.04.025

821 Rodolfo-Metalpa, R., Houlbrèque, F., Tambutté, É., Boisson, F., Baggini, C., Patti, F. P., ... 822 Hall-Spencer, J. (2011). Coral and mollusc resistance to ocean acidification adversely affected 823 by warming. Nature Climate Change, 1(9), 1-5. https://doi.org/10.1038/nclimate1200

824 Savolainen, O., Lascoux, M., \& Merilä, J. (2013). Ecological genomics of local adaptation.

$825 \quad$ Nature Reviews Genetics, 14(11), 807-820. https://doi.org/10.1038/nrg3522

826 Swain, T. D., Bold, E. C., Osborn, P. C., Baird, A. H., Westneat, M. W., Backman, V., \&

827 Marcelino, L. A. (2018). Physiological integration of coral colonies is correlated with

828 bleaching resistance. Marine Ecology Progress Series, 586, 1-10.

829 https://doi.org/10.3354/meps12445

830 Takeshita, Y., Frieder, C. A., Martz, T. R., Ballard, J. R., Feely, R. A., Kram, S., ... Smith, J. E. 831 (2015). Including high frequency variability in coastal ocean acidification projections.

832 Biogeosciences (Vol. 12). https://doi.org/10.5194/bgd-12-7125-2015

833 Tambutté, E., Venn, A. A., Holcomb, M., Segonds, N., Techer, N., Zoccola, D., ... Tambutté, S. 834 (2015). Morphological plasticity of the coral skeleton under $\mathrm{CO}_{2}$-driven seawater acidification. 
Nature Communications, 6(7368), 1-9. https://doi.org/10.1038/ncomms8368

836

837

838

839

840

841

842

843

844

845

846

847

848

849

850

851

852

853

854

Teixidó, N., Gambi, M. C., Parravicini, V., Kroeker, K., Micheli, F., Villéger, S., \& Ballesteros, E. (2018). Functional biodiversity loss along natural $\mathrm{CO}_{2}$ gradients. Nature Communications, 9, 5149. https://doi.org/10.1038/s41467-018-07592-1

Thomas, L., Rose, N. H., Bay, R. A., López, E. H., Morikawa, M. K., Ruiz-Jones, L., \& Palumbi, S. R. (2018). Mechanisms of thermal tolerance in reef-building corals across a fine-grained environmental mosaic: lessons from Ofu, American Samoa. Frontiers in Marine Science, 4, 434. https://doi.org/10.3389/fmars.2017.00434

Tresguerres, M. (2016). Novel and potential physiological roles of vacuolar-type $\mathrm{H}^{+}$-ATPase in marine organisms. Journal of Experimental Biology, 219(14), 2088-2097.

https://doi.org/10.1242/jeb.128389

Turner, J. S. (1973). Buoyancy Effects in Fluids. Cambridge University Press.

Zebral, Y. D., Da Silva Fonseca, J., Marques, J. A., \& Bianchini, A. (2019). Carbonic anhydrase as a biomarker of global and local impacts: Insights from calcifying animals. International Journal of Molecular Sciences, 20(12), 1-16. https://doi.org/10.3390/ijms20123092

Zibrowius, H. (1995). The "southern" Astroides calycularis in the Pleistocene of the northern Mediterranean-An indicator of climatic changes (Cnidaria, Scleractinia). Geobios, 28, 9-16.

Zoccola, D., Innocenti, A., Bertucci, A., Tambutté, E., Supuran, C. T., \& Tambutté, S. (2016). Coral carbonic anhydrases: Regulation by ocean acidification. Marine Drugs, 14, 109. https://doi.org/10.3390/md14060109 


\section{ACKNOWLEDGEMENTS}

857 We thank P. Sorvino (ANS Diving, Ischia), A. Passaretti and E. Di Meglio for their field assistance.

858 We also thank S. Durante (Rizzoli Orthopaedic Institute of Bologna) for assistance in performing 859 computerized tomography scans and F. Italiano (National Institute of Geophysics and 860 Volcanology) for the gas data. N.T. thanks M. Khamla for assistance in Figure 7 and E. Ferrer for 861 English grammar reviewing. Funding: This research was supported by the Total Foundation 862 (High- $\mathrm{CO}_{2}$ Seas grant, Grant No. BIO-2016-081-4), the French National Research Agency 863 (4Oceans-MOPGA grant, ANR-17-MPGA-0001), and the ALMA IDEA (STRAMICRO grant, 864 University of Bologna). N.T. was supported by a Maire Curie-Cofund (FP7-PEOPLE-Marie Curie 865 Bandiera-Cofund, GA No. 600407) and by a Marie Sklodowska-Curie Global Fellowship under 866 the European Union's Horizon 2020 research and innovation programme (H2020- MSCA- IF867 2015, GA No. 702628).

868 DATA AVAILABILITY STATEMENT

869 RNASeq FASTQ files for all 41 samples sequenced in this study were deposited in the NCBI Short 870 Read Archive (SRA) under BioProject PRJNA643775 (Accession numbers SRR12135922 871 SRR12135962), https:/dataview.ncbi.nlm.nih.gov/object/PRJNA643775?reviewer=5j14na61906tr4dne0bvg9kbhq.

872 The de novo transcriptome assembly generated in this study and used for mapping the samples has 873 been deposited in the NCBI Transcriptome Shotgun Assembly (TSA) database at 874 DDBJ/ENA/GenBank under accession number $\quad$ GIRZ01000000

875 (https://www.ncbi.nlm.nih.gov/nuccore/GIRZ00000000). The version described in this paper 876 is the first version, GIRZ01000000. The bioinformatics scripts used for assembly, mapping, and 877 SNP-calling are available on Github at DOI: 10.5281/zenodo.3934433. 


\section{AUTHOR CONTRIBUTIONS}

880 N.T., E.C., S.P., E.S., S.G., M.C.G designed the study. N.T., E.C., S.A., S.C., F.M., A.M., M.M., 881 S.P., E.S., L.U., C.d.V, M.C.G were involved with fieldwork. N.T., S.A., J.P.G., A.M., S.G.M., 882 L.U., C.d.V. analyzed the environmental data; E.C., C.C., P.F., S.G. analyzed the skeletal data; E.

883 S., S. P., and N.T analyzed the genomic data. N.T. drafted the initial manuscript and all authors 884 contributed discussion, writing and interpretation.

885 COMPETING INTERESTS

886 The authors declare that they have no competing interests.

887 ETHICAL STATEMENT

888 All work undertaken in this study complied with current laws of Italy and United States of America

889 for collecting and importing/exporting coral specimens. Cites permits IT/EX/2018/MCE/00170, 890 IT/EX/2017/MCE/00214, IT/EX/2017/MCE/00325. 
896

897

898

899

900

901

902

903

904

905

906

907

908

909

910

911

912

913

914

915

916

917

918

919

\section{FIGURES AND TABLES}

A)

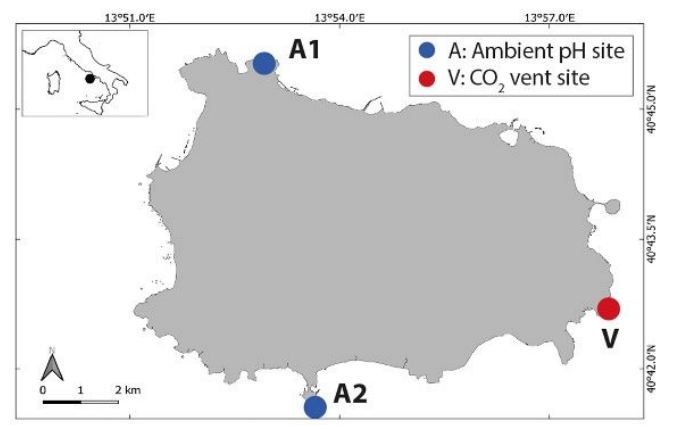

B)

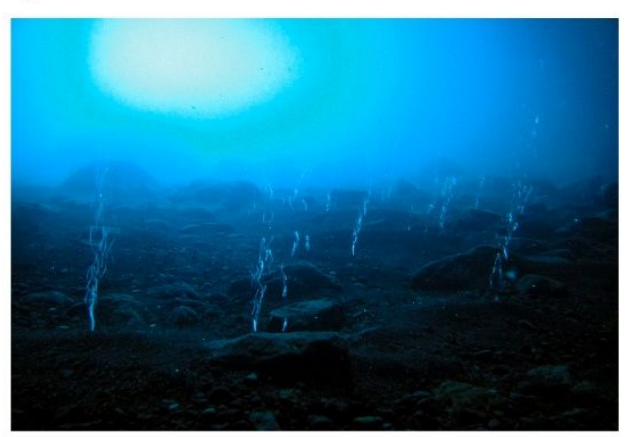

D) September 2018
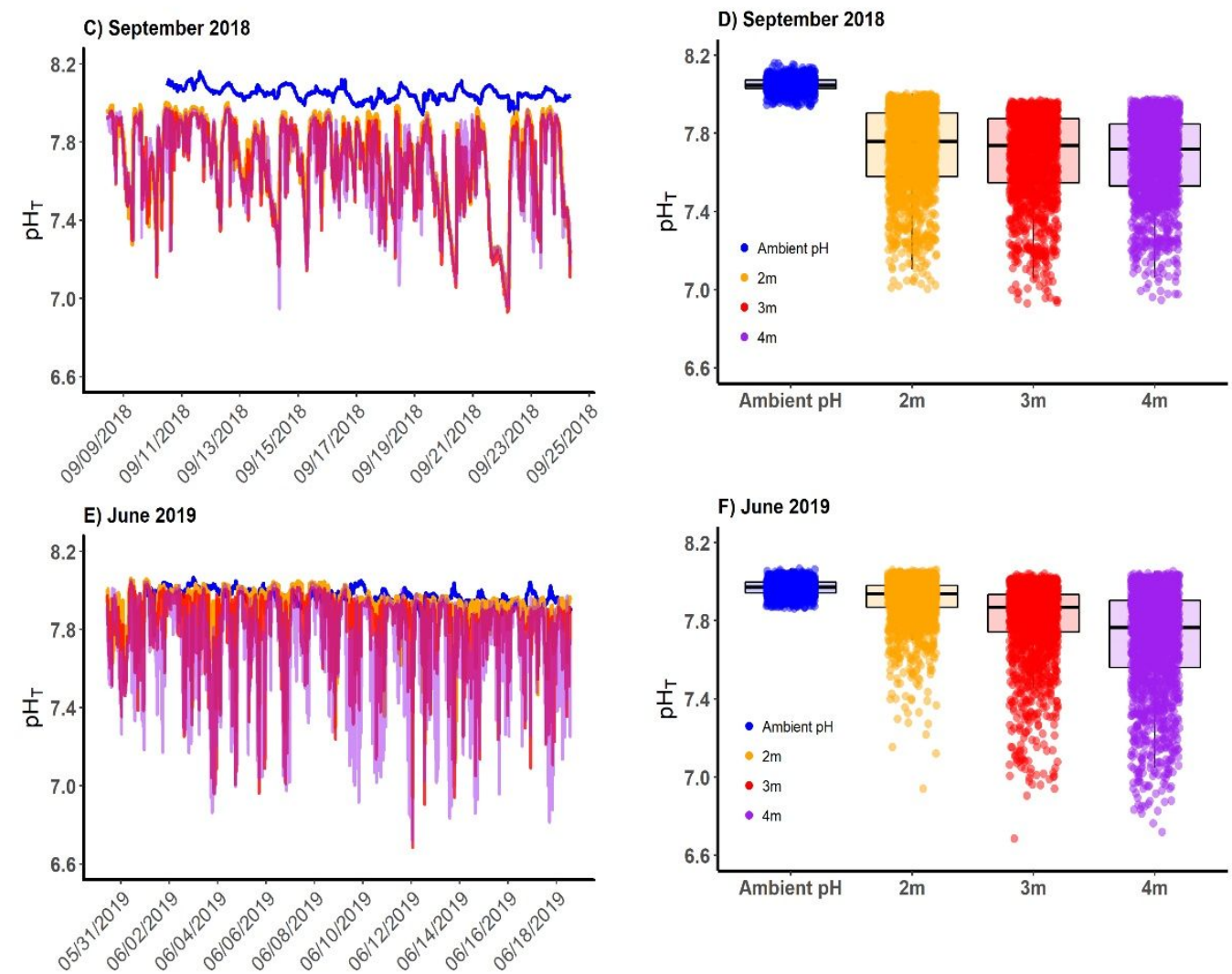

FIGURE 1. New $\mathrm{CO}_{2}$ vent system and $\mathrm{pH}$ time series and variability. A) Map showing the location of the study sites along the coast of Ischia Island, Italy. V refers to the $\mathrm{CO}_{2}$ vent system named Grotta del Mago: A1 (Ambient 1, Punta Vico) and A2 (Ambient 2, Sant'Angelo) are offvent reference sites with ambient $\mathrm{pH}$. B) The underwater volcanic vents occur in a semi-submerged cave at $5 \mathrm{~m}$ depth, release continuously gaseous emissions $\left(92-95 \% \mathrm{CO}_{2}\right.$, no sulfur), and do not 
920 elevate temperature (Supporting Note 1, Figure S1, Tables S1, S5). C, E) Time series and D, F) 921 and $\mathrm{pH}_{\mathrm{T}}$ (total scale) variability at the $\mathrm{CO}_{2}$ vent site at $2 \mathrm{~m}$ (orange), $3 \mathrm{~m}$ (red), and $4 \mathrm{~m}$ (violet) 922 depth and at reference sites at $2 \mathrm{~m}$ with ambient $\mathrm{pH}$ (blue). Dates of $\mathrm{pH}_{\mathrm{T}}$ series: from September 8 923 to September 24, $2018\left(n=1530\right.$ for each depth at the $\mathrm{CO}_{2}$ vent site and $n=1331$ for the ambient $924 \mathrm{pH}$ site 1), and from May 30 to June $18,2019\left(\mathrm{n}=1840\right.$ for each depth at the $\mathrm{CO}_{2}$ vent site and $\mathrm{n}=$ 9251691 for the ambient $\mathrm{pH}$ site 2). Measurements were taken every 15 minutes using SeaFETs 926 sensors.

927 
A)
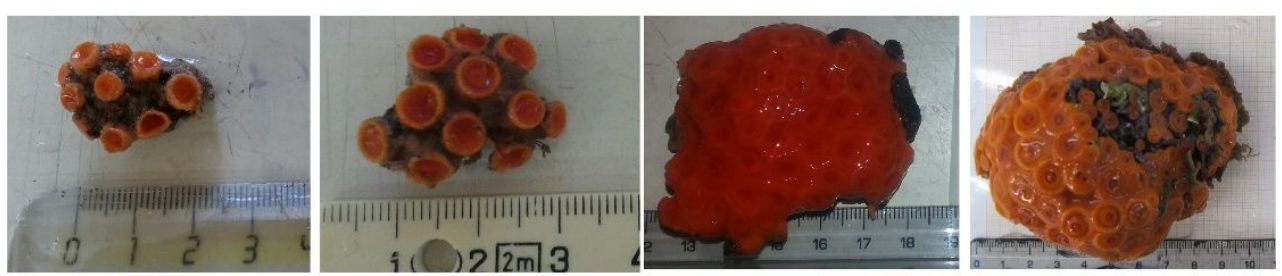

B)

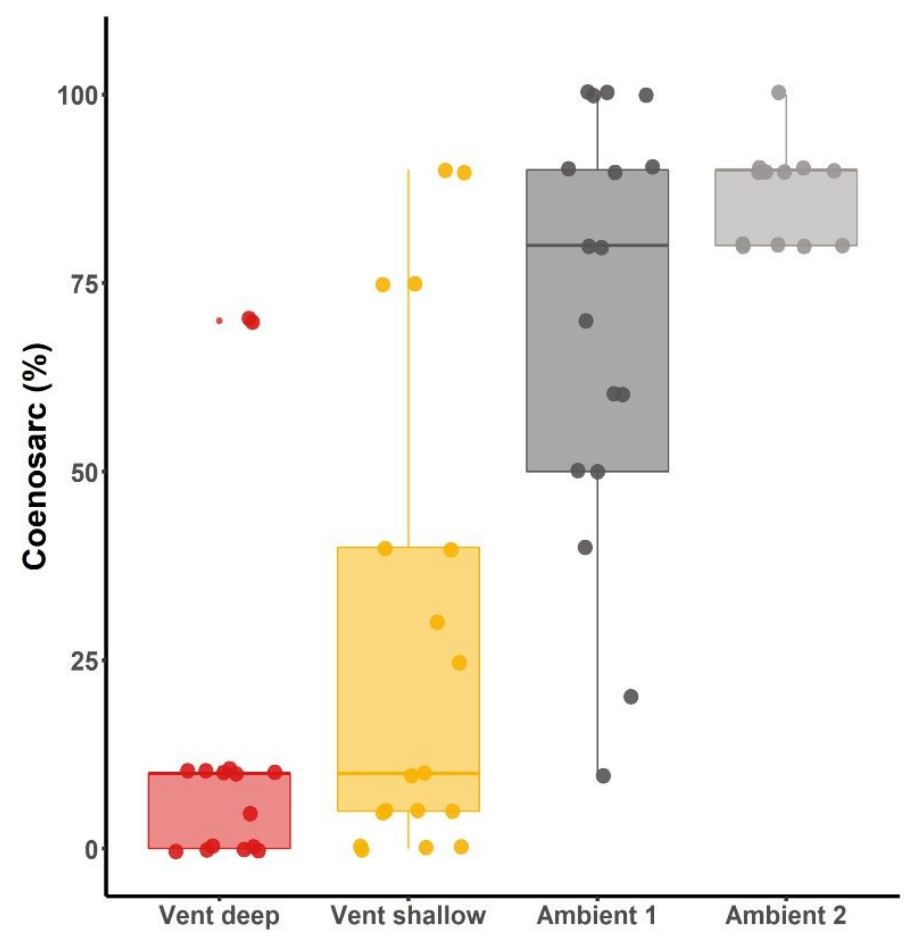

942 FIGURE 2. A) Photographs showing colonies sampled for skeletal characteristics and growth of

943 the $\mathrm{CO}_{2}$ vent system and off-vent reference sites with ambient $\mathrm{pH}$. Vent system deep (3 m depth);

944 Vent system shallow (1 - $2 \mathrm{~m}$ depth), Ambient 1= Punta Vico (1 - $2 \mathrm{~m}$ depth); Ambient $2=$

945 Sant'Angelo (1 - $2 \mathrm{~m}$ depth). Colonies in the vent system exhibited encrusting form (flat growth

946 form), whereas colonies in Ambient $\mathrm{pH}$ sites were a mixture of massive (extensive vertical and

947 lateral growth) and encrusting forms (see also Figure S7). B) \% Coenosarc (the living tissue

948 connecting the polyps) of colonies among the study sites. Significant differences were found 949 between vent (shallow and deep) and ambient $\mathrm{pH}$ populations $\left(\mathrm{F}_{3,58}=24.9, \mathrm{p}<0.0001\right.$; pair-wise 
950 comparisons between vent system deep -shallow and off-vent reference sites $p<0.0001$ ). Number 951 of colonies $=66$. 
952

953

954

955

956

957

958

959

960

961

962

963

964

965

966

967

968

969

970

971

972

973

974

976

977

975 deep, number of colonies $=16 ; \mathrm{Vs}=$ Vent system shallow, number of colonies $=18 ; \mathrm{A} 1=\mathrm{Ambient}$

A)
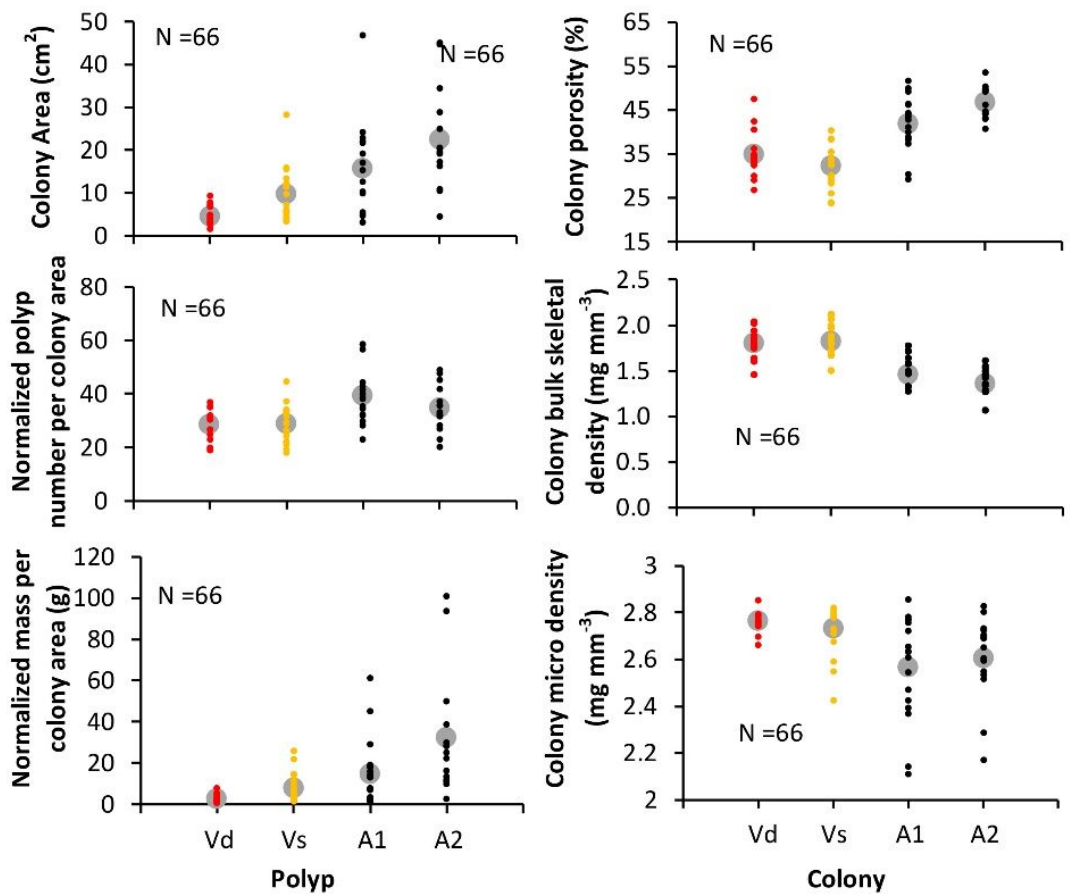

B)
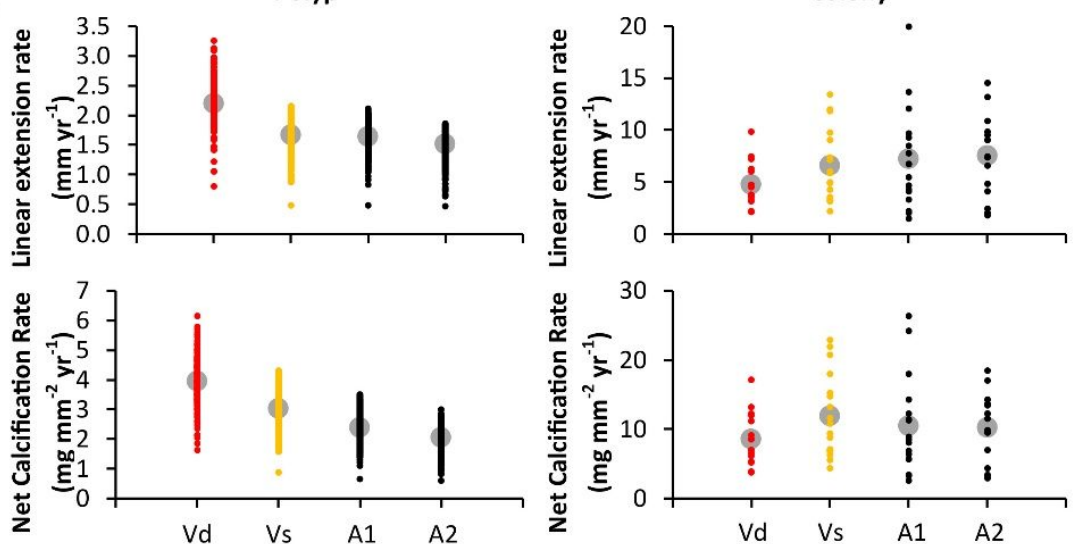

FIGURE 3. Skeletal and growth parameters measured in A. calycularis. A) Skeletal

72 parameters of colonies and B) Growth parameters at polyp and colony levels at the $\mathrm{CO}_{2}$ vent site

(Vd and Vs) and ambient $\mathrm{pH}$ conditions (A1 and A2), respectively. Colony mass and polyp number

74 were normalized to colony area. Grey circles in the plot represent the mean. $\mathrm{Vd}=\mathrm{Vent}$ system

761 , number of colonies $=17 ;$ A2 $=$ Ambient 2, number of colonies $=15$. Total number of colonies

analyzed $=66$. 
978

979

980

981

982

983

984

985

986

987

988

989

990

991

992

993

994

995

996

997

998

999

1000

1001

1002

1003
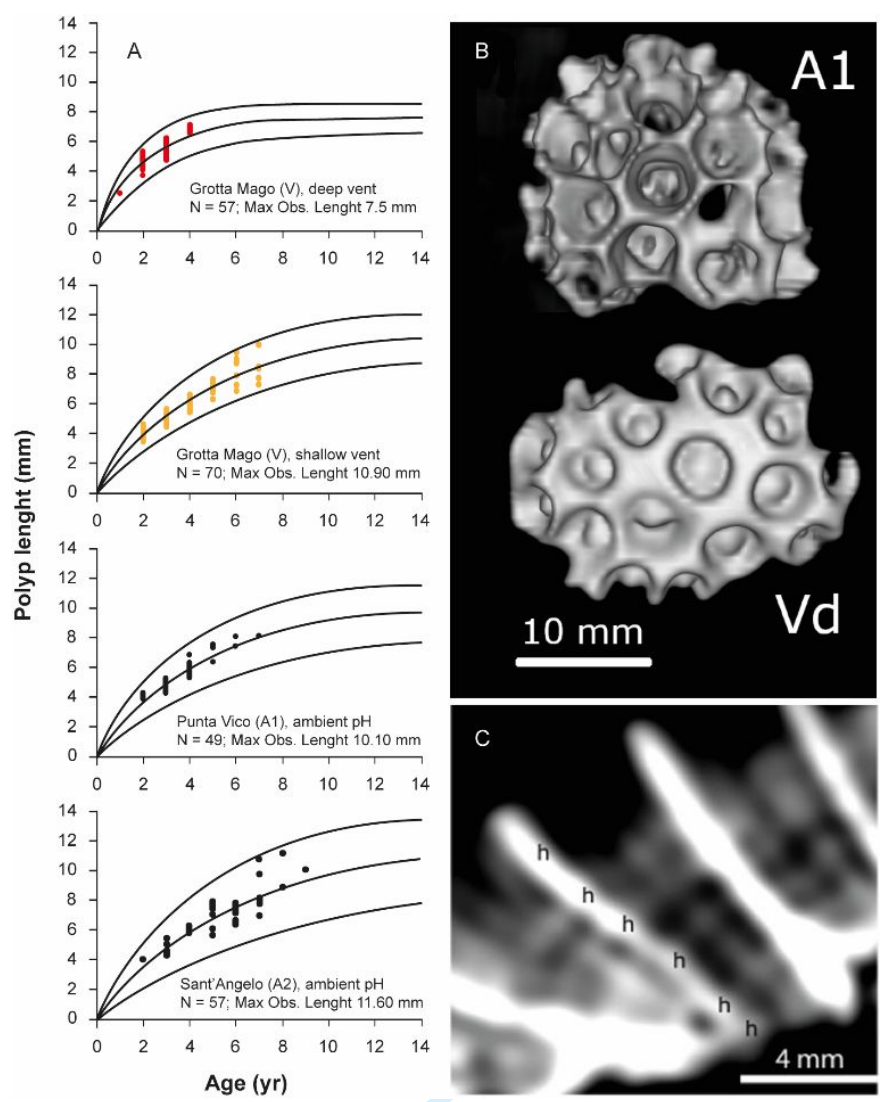

FIGURE 4. Relationships between age-length growth curves of $\boldsymbol{A}$. calycularis. A) Age-length

von Bertalanffy growth curves at the polyp (corallite) level. Dots indicate the age determined by counting the growth bands on computerized tomography. Lines indicate the mean von Bertalanffy growth curve and the $95 \%$ confidence interval). Values of $\mathrm{L}_{\infty}$ (maximum expected length in the population) and K (a growth constant, larger for fast growth) were: $7.6 \mathrm{~mm}$ and 0.5 for Vent deep; $11.0 \mathrm{~mm}$ and 0.2 for Vent shallow; $10.2 \mathrm{~mm}$ and 0.2 for Ambient 1 ; and $11.8 \mathrm{~mm}$ and 0.17 for Ambient 2, respectively. B) Surface 3D rendering of the CT scans performed on a colony of $A$. calycularis from Ambient 1 (A1) and on another colony of similar surface area from Vent deep $(\mathrm{Vd})$. Photograph of the deep vent $(\mathrm{Vd})$ colony shows that same calcification is allocated to a minor number of polyps, and these few polyps result in having a more dense skeleton. C) Computerized tomography scan to count the growth bands on a single corallite. In this photograph, the corallite of $A$. calycularis is 6 years old; h indicates high density annual bands. 
1004

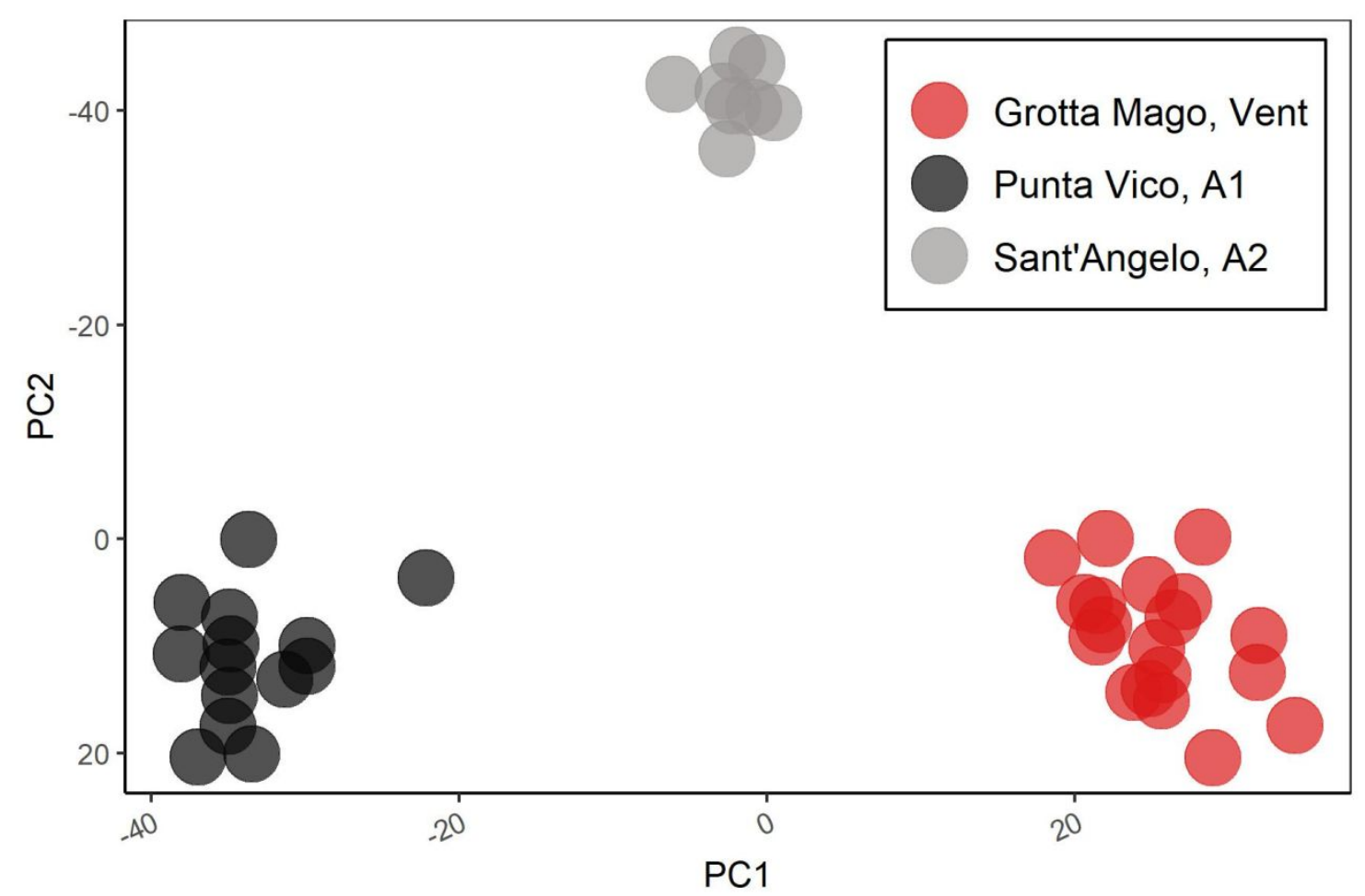

1005

1006 FIGURE 5. Population genetic structure of $\boldsymbol{A}$. calycularis based on 46,784 single nucleotide

1007 polymorphisms (SNPs). Number of individuals: $\mathrm{CO}_{2}$ vent site (Vent, Grotta Mago)=19; ambient 1008 pH sites: Ambient $1($ A1, Punta Vico $)=14$, Ambient $2($ A2, Sant' Angelo $)=8$. 

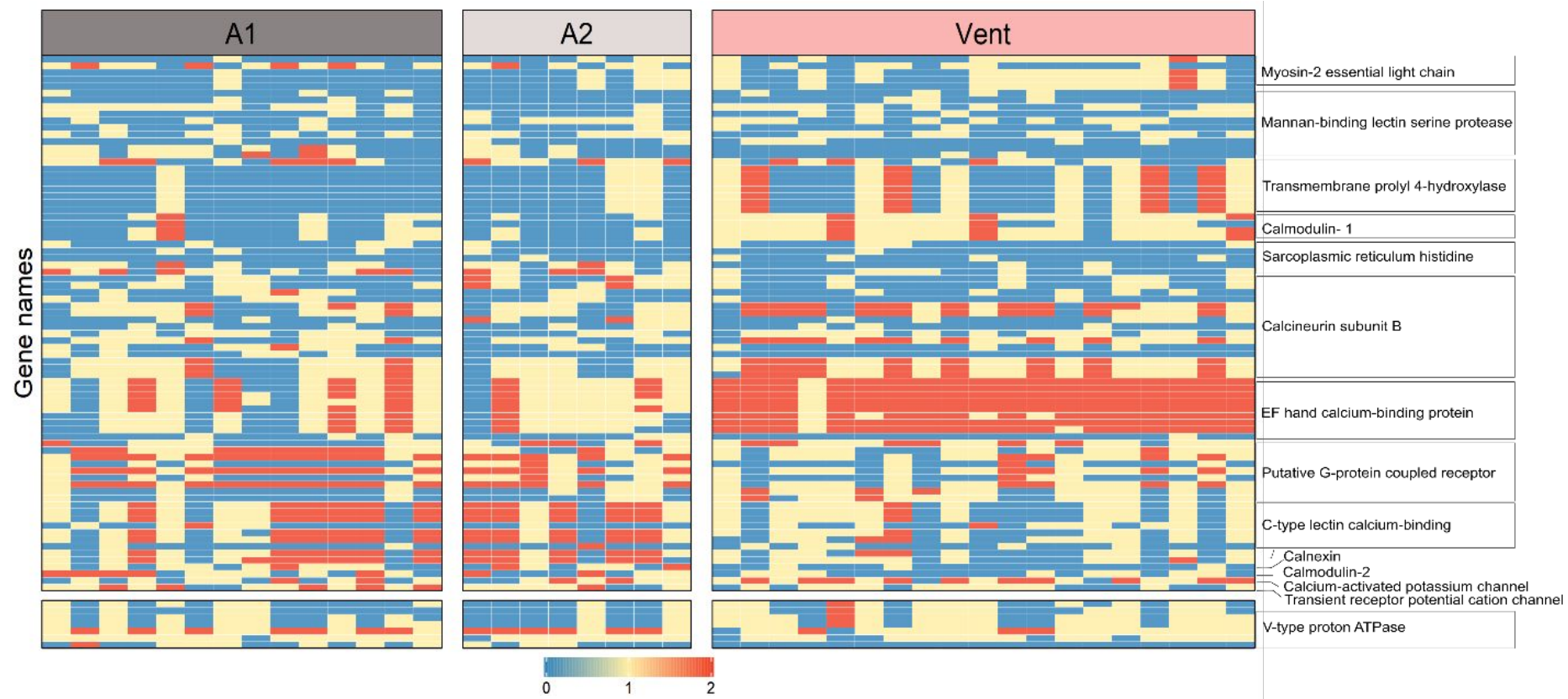

1012 FIGURE 6. Upper: SNP genotypes for 13 calcium ion related loci showing high levels of 1013 divergence in the Grotta Mago population. Lower: Genotypes for 7 SNPs within a highly 1014 differentiated V-type proton ATPase potentially involved in $\mathrm{pH}$ regulation in the calicoblastic 1015 layer where calcification occurs. Vent: $\mathrm{CO}_{2}$ vent (Grotta Mago), A1: Ambient 1 (Punta Vico); A2: 1016 Ambient 2 (Sant'Angelo). Legend: $0=$ homozygous major allele, $1=$ heterozygous; $2=$ 1017 homozygous minor allele. 

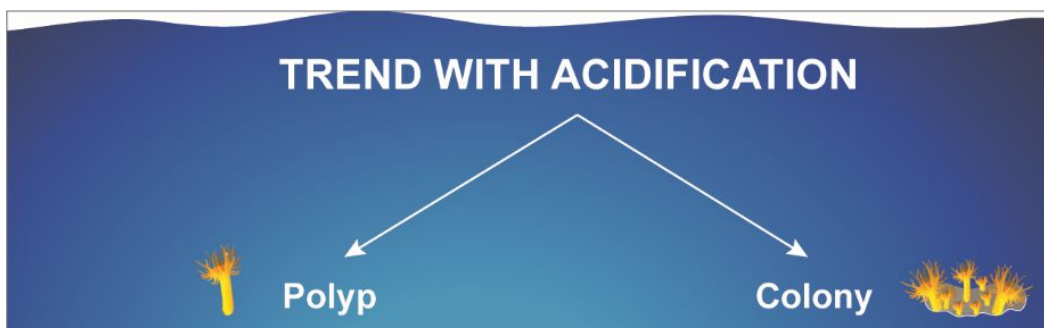

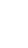

1033

1034

FIGURE 7. Schematic summary of the responses on skeletal and growth parameters to ocean 1036 acidification measured in the coral $A$. calycularis at the polyp and colony levels. 
1038 TABLE 1. Measured and estimated seawater physiochemical parameters at the $\mathrm{CO}_{2}$ vent site and 1039 reference areas with ambient $\mathrm{pH}$ for salinity $(\mathrm{S})$, temperature $(\mathrm{T})$, total alkalinity $\left(\mathrm{A}_{\mathrm{T}}\right)$, dissolved 1040 inorganic carbon $\left(\mathrm{C}_{\mathrm{T}}\right), \mathrm{pH}_{\mathrm{T}}, p \mathrm{CO}_{2}$, calcite $(\Omega \mathrm{c})$ and aragonite $(\Omega \mathrm{a})$ saturation. Values are means, \pm $1041 \mathrm{SD}$ with 25th and 75th percentiles. Calculated concentrations of $\mathrm{C}_{\mathrm{T}}, p \mathrm{CO}_{2}, \Omega \mathrm{c}$ and $\Omega \mathrm{a}$ are shown.

1042 1: Parameters measured from discrete water samples; 2: parameters measured with in situ sensors.

1043 For detailed SeaFET pH sensor statistics and the carbonate system parameters, see Figure S5 and 1044 Table S5, respectively.

\begin{tabular}{|c|c|c|c|c|c|}
\hline & \multicolumn{3}{|c|}{ Vent site (GM) } & \multirow{2}{*}{$\begin{array}{c}\text { A1-PV } \\
2 \mathrm{~m}\end{array}$} & \multirow{2}{*}{$\begin{array}{c}\text { A2-SA } \\
2 \mathrm{~m}\end{array}$} \\
\hline Month/year & $2 m$ & $3 \mathrm{~m}$ & $4 \mathrm{~m}$ & & \\
\hline \multicolumn{6}{|l|}{ September 2018} \\
\hline $\mathrm{S}$ & $\begin{array}{c}37.3^{1} \pm 0.2 \\
(37.2,37.5), \mathrm{n}=9\end{array}$ & $\begin{array}{c}37.3^{1} \pm 0.2 \\
(37.2,37.5), \mathrm{n}=9\end{array}$ & $\begin{array}{c}37.3^{1} \pm 0.2 \\
(37.2,37.5), \mathrm{n}=9\end{array}$ & $\begin{array}{c}37.3^{1} \pm 0 \\
(37.3,37.3), n=5\end{array}$ & $\begin{array}{c}37.4^{1} \pm 0 \\
(37.4,37.4), n=3\end{array}$ \\
\hline $\mathrm{T}\left({ }^{\circ} \mathrm{C}\right)$ & $\begin{array}{c}25.9^{2} \pm 0.2 \\
(25.8,26.0), n=1530\end{array}$ & $\begin{array}{c}26.0^{2} \pm 0.2 \\
(25.8,26.0), n=1530\end{array}$ & $\begin{array}{c}26.0^{2} \pm 0.2 \\
(25.9,26.1), n=1530\end{array}$ & $\begin{array}{c}17.3^{2} \pm 0.4 \\
(17.0,17.6), n=1331^{2}\end{array}$ & $\begin{array}{c}25.9^{2} \pm 0.2 \\
(59.9,26.1), \mathrm{n}=408\end{array}$ \\
\hline $\mathrm{A}_{\mathrm{T}}\left(\mu \mathrm{mol} \mathrm{kg} \mathrm{kg}^{-1}\right)$ & $\begin{array}{c}2564^{1} \pm 7 \\
(2561,2566), n=9\end{array}$ & $\begin{array}{c}2562 \pm 8 \\
(2557,2565), n=9\end{array}$ & $\begin{array}{c}2562^{1} \pm 8 \\
(2556,2566), n=9\end{array}$ & $\begin{array}{c}2618^{1} \pm 15 \\
(2607,2633), n=5\end{array}$ & $\begin{array}{c}2610^{1} \pm 1 \\
(2609,2611), n=3\end{array}$ \\
\hline $\mathrm{C}_{\mathrm{T}}\left(\mu \mathrm{mol} \mathrm{kg} \mathrm{kg}^{-1}\right)$ & $\begin{array}{c}2542 \pm 79 \\
(2477,2585), n=1530\end{array}$ & $\begin{array}{c}2552 \pm 84 \\
(2485,2593), n=1530\end{array}$ & $\begin{array}{c}2555 \pm 80 \\
(2495,2598), n=1530\end{array}$ & $\begin{array}{c}2262 \pm 24 \\
(2246,2276), n=1331\end{array}$ & $\begin{array}{c}2275 \pm 1 \\
(2275,2276), n=3 \\
\end{array}$ \\
\hline $\mathrm{pH}_{\mathrm{T}}$ & $\begin{array}{c}7.65^{2} \\
(7.58,7.90), n=1530\end{array}$ & $\begin{array}{c}7.62^{2} \\
(7.55,7.87), n=1530\end{array}$ & $\begin{array}{c}7.60^{2} \\
(7.53,7.85), n=1530\end{array}$ & $\begin{array}{c}8.05^{2} \\
(8.03,8.07), \mathrm{n}=1331 \\
\end{array}$ & $\begin{array}{c}8.02^{1} \\
(8.02,8.03), n=3\end{array}$ \\
\hline$p \mathrm{CO}_{2}(\mu \mathrm{atm})$ & $\begin{array}{c}2905 \pm 1664 \\
(1724,3438), n=1530\end{array}$ & $\begin{array}{c}3146 \pm 1928 \\
(1837,3668), n=1530 \\
\end{array}$ & $\begin{array}{c}3192 \pm 1806 \\
(1958,3799), n=1530\end{array}$ & $\begin{array}{c}322 \pm 34 \\
(298,341), n=1331\end{array}$ & $\begin{array}{c}375 \pm 1 \\
(374,375), n=3\end{array}$ \\
\hline$\Omega \mathrm{c}$ & $\begin{array}{c}1.68 \pm 0.59 \\
(1.21,2.21), \mathrm{n}=1530\end{array}$ & $\begin{array}{c}1.58 \pm 0.56 \\
(1.14,2.09), \mathrm{n}=1530\end{array}$ & $\begin{array}{c}1.54 \pm 0.54 \\
(1.10,1.98), \mathrm{n}=1530\end{array}$ & $\begin{array}{c}5.96 \pm 0.36 \\
(5.74,6.21), \mathrm{n}=1331 \\
\end{array}$ & $\begin{array}{c}5.70 \pm 0.01 \\
(5.69,5.70), \mathrm{n}=3 \\
\end{array}$ \\
\hline$\Omega \mathrm{a}$ & $\begin{array}{c}1.11 \pm 0.39 \\
(0.80,1.47), \mathrm{n}=1530\end{array}$ & $\begin{array}{c}1.05 \pm 0.37 \\
(0.75,1.39), n=1530\end{array}$ & $\begin{array}{c}1.02 \pm 0.36 \\
(0.73,1.32), n=1530\end{array}$ & $\begin{array}{c}3.86 \pm 0.23 \\
(3.72,4.02), n=1331\end{array}$ & $\begin{array}{c}3.71 \pm 0.01 \\
(3.70,3.71), n=3\end{array}$ \\
\hline \multicolumn{6}{|l|}{ June 2019} \\
\hline $\mathrm{S}$ & $\begin{array}{c}37.8^{1} \pm 0 \\
(37.8,37.8), \mathrm{n}=7 \\
\end{array}$ & $\begin{array}{c}37.8^{1} \pm 0 \\
(37.8,37.8), \mathrm{n}=7\end{array}$ & $\begin{array}{c}37.8^{1} \pm 0 \\
(37.8,37.8), \mathrm{n}=7\end{array}$ & $\begin{array}{c}38.0^{1} \pm 0 \\
(38.0,38.0), \mathrm{n}=3 \\
\end{array}$ & $\begin{array}{c}37.9^{1} \pm 0 \\
(37.9,37.9), \mathrm{n}=7 \\
\end{array}$ \\
\hline $\mathrm{T}\left({ }^{\circ} \mathrm{C}\right)$ & $\begin{array}{c}21.9^{2} \pm 2.1 \\
(19.9,24.1), n=1840\end{array}$ & $\begin{array}{c}21.8^{2} \pm 2.1 \\
(19.8,23.8), \mathrm{n}=1840^{2}\end{array}$ & $\begin{array}{c}21.7^{2} \pm 2.0 \\
(19.6,23.4), n=1840^{2}\end{array}$ & $\begin{array}{c}26.2^{2} \pm 0.2 \\
(26.1,26.3), n=408\end{array}$ & $\begin{array}{c}26.2^{2} \pm 1.1 \\
(25.8,27.0), \mathrm{n}=1691^{2}\end{array}$ \\
\hline $\mathrm{A}_{\mathrm{T}}\left(\mu \mathrm{mol} \mathrm{kg}{ }^{-1}\right)$ & $\begin{array}{c}2539^{1} \pm 22 \\
(2593,2552), n=7\end{array}$ & $\begin{array}{c}2541^{1} \pm 20 \\
(2532,2550), n=7\end{array}$ & $\begin{array}{c}2551^{1} \pm 22 \\
(2538,2568), n=7\end{array}$ & $\begin{array}{c}2630^{1} \pm 1 \\
(2630.1,2630.9), n=3\end{array}$ & $\begin{array}{c}2642^{1} \pm 17 \\
(2629,2659), n=7\end{array}$ \\
\hline $\mathrm{C}_{\mathrm{T}}\left(\mu \mathrm{mol} \mathrm{kg} \mathrm{kg}^{-1}\right)$ & $\begin{array}{c}2450 \pm 42 \\
(2424,2464), n=1840\end{array}$ & $\begin{array}{c}2489 \pm 75 \\
(2443,2509), n=1840\end{array}$ & $\begin{array}{c}2535 \pm 104 \\
(2461,2574), n=1840\end{array}$ & $\begin{array}{c}2336 \pm 3 \\
(2320,2353), n=3 \\
\end{array}$ & $\begin{array}{c}2336 \pm 23 \\
(2320,2353), n=1691\end{array}$ \\
\hline $\mathrm{pH}_{\mathrm{T}}$ & $\begin{array}{c}7.88^{2} \\
(7.86,7.98), n=1840\end{array}$ & $\begin{array}{c}7.74^{2} \\
(7.74,7.93), n=1840\end{array}$ & $\begin{array}{c}7.60^{2} \\
(7.56,7.90), n=1840\end{array}$ & $\begin{array}{c}8.04^{1} \\
(8.04,8.04), n=3 \\
\end{array}$ & $\begin{array}{c}7.97^{2} \\
(7.94,7.99), \mathrm{n}=1691\end{array}$ \\
\hline$p \mathrm{CO}_{2}(\mu \mathrm{atm})$ & $\begin{array}{c}1531 \pm 627 \\
(1167,1653), n=1840\end{array}$ & $\begin{array}{c}2082 \pm 1502 \\
(1352,2127), n=1840\end{array}$ & $\begin{array}{c}2812 \pm 2310 \\
(1495,3090), n=1840\end{array}$ & $\begin{array}{c}372 \pm 1 \\
(372,373), n=3\end{array}$ & $\begin{array}{c}586 \pm 76 \\
(532,635), n=1691\end{array}$ \\
\hline$\Omega \mathrm{c}$ & $\begin{array}{c}2.20 \pm 0.41 \\
(2.01,2.46), n=1840\end{array}$ & $\begin{array}{c}1.87 \pm 0.54 \\
(1.57,2.26), \mathrm{n}=1840\end{array}$ & $\begin{array}{c}1.60 \pm 0.65 \\
(1.10,2.14), n=1840\end{array}$ & $\begin{array}{c}5.92 \pm 0.01 \\
(5.92,5.93), n=3\end{array}$ & $\begin{array}{c}5.34 \pm 0.35 \\
(5.08,5.58), n=1691\end{array}$ \\
\hline$\Omega \mathrm{a}$ & $\begin{array}{c}1.44 \pm 0.27 \\
(1.32,1.61), \mathrm{n}=1840\end{array}$ & $\begin{array}{c}1.23 \pm 0.35 \\
(1.03,1.48), \mathrm{n}=1840\end{array}$ & $\begin{array}{c}1.05 \pm 0.42 \\
(0.72,1.40), \mathrm{n}=1840\end{array}$ & $\begin{array}{c}3.89 \pm 0.01 \\
(3.86,3.87), \mathrm{n}=3\end{array}$ & $\begin{array}{c}3.54 \pm 0.23 \\
(3.38,3.71), n=1691\end{array}$ \\
\hline
\end{tabular}

1045

1046 